\title{
Synthesis, Electronic Structure and Molecular Docking of New Organometallic Palladium (II) Complexes with IntercalatorLignads: The Influence of Bridged Ligands on Enhanced DNA/Serum Protein Binding and in VitroAntitumoral Activity
}

\author{
Kazem Karami, ${ }^{\text {a }}$ Zohreh Mehri Lighvan, ${ }^{a}$ Maryam Dehdashti Jahromi, ${ }^{\text {a } J a n u s z ~ L i p k o w s k i ~}{ }^{b}$ and Amir Abbas \\ Momtazi-borojeni $^{c}$ \\ ${ }^{a}$ Department of Chemistry, Isfahan University of Technology, Isfahan, 84156/83111, Iran \\ ${ }^{b}$ Institute of Physical Chemistry, Polish Academy of Sciences, Kasprzaka 44/52, 01-224 Warsaw, Poland \\ ${ }^{c}$ Student Research Committee, Nanotechnology Research Center, Department of Medical Biotechnology, School of Medicine, Mashhad \\ University of Medical Sciences, Mashhad, Iran
}

\begin{abstract}
Novel organometallic palladium(II) complexes $\left.\quad\left[\mathrm{Pd}_{2}\left\{(\mathrm{C}, \mathrm{N})-\mathrm{C}_{12} \mathrm{H}_{8} \mathrm{NH}_{2}\right)\right\}_{2}(\mu-\mathrm{dppf}) \mathrm{Cl}_{2}\right] \quad(2) \quad\left[\mathrm{Pd}_{2}\{(\mathrm{C}, \mathrm{N})-\right.$ $\left.\left.\mathrm{C}_{12} \mathrm{H}_{8} \mathrm{NH}_{2}\right)\right\}_{2}\left(\mu\right.$-dpp)Cl $\mathrm{Cl}_{2}$ (3) [1,1-bis(diphenylphosphine)-ferrocene (dppf), 1,3-Bis(4-pyridyl)propane (bpp)] have been synthesized, fully characterized by elemental analysis, multi-nuclear $\left({ }^{1} \mathrm{H},{ }^{31} \mathrm{P}\{1 \mathrm{H}\},{ }^{13} \mathrm{C}\{1 \mathrm{H}\}\right) \mathrm{NMR}$ and IR spectroscopic techniquesand their biological activities such as anti-tumoralactivity and DNA-protein interactions have been investigated. The crystal structure of (2), established by X-ray diffraction, shows that the dppf ligand is bound to the two palladium atoms in bridgedform. The interaction of the complexes with calf thymus DNA (CTDNA) has been explored by UV-Vis spectroscopy, emission titration and thermal denaturation ( $\left.\mathrm{T}_{\mathrm{m}}\right)$ methods, which have revealed that these complexes interact with DNA through intercalation mode. Competitive studies with methylene blue (MB) have shown the ability of the complexes to displace the DNAbound MB, suggesting a competition with MB. Furthermore, the microenvironment and the secondary structure of BSA are changed in the presence of the complexes. Competitive binding using Warfarin, Digoxin and site markers, which have definite binding sites, demonstrated that the complexes bind to site I on BSA. Notably, the complexes exhibit significant in vitro selective cytotoxicity against two human cancer cell lines (JURKAT and SKOV3) with $\mathrm{IC}_{50}$ values varying from 2.3 to $6.7 \mu \mathrm{M}$. This indicates that they are more active than cisplatin and showing low cytotoxic activity on normal cells. Finally, molecular modelling studies have been conducted to determine the binding site of the DNA and BSA with the complexes.
\end{abstract}

Keywords: Palladacycle; DNA-binding; BSA binding; site markers

Corresponding author: KazemKarami; Tel: +983133913239; fax: +983133912350

E-mail addresses: karami@cc.iut.ac.ir(KazemKarami), 


\section{Introduction}

Development of new metal-containing anticancer therapeutic agents has historically been one of the fundamental goals in medicinal chemistry. The success of organo-transition metal compounds in combating against diseases, particularly cancer, has very obviously increasing interest in the design of pharmaceuticals based on organometallic compounds [1]. Organometallic compounds can provide more suitable drug candidates than the inorganic complexes due to their less complicated ligand exchange chemistry. Nevertheless, cyclopalladated complexes are more stable and most importantly, less toxic, suggesting they could have more specific antitumor activity in vivo, compared to many platinum based anticancer compounds $[2,3,4,5,6]$. Deoxyribonucleic acid (DNA) is generally the primary intracellular target of anticancer drugs. Therefore, the interaction between transition metal compounds and DNA can cause DNA damage in cancer cells, blocking their division and leading to cell death $[7,8,9,10]$. In general, most compounds have three distinct modes of non-covalent interaction with DNA, i.e. intercalative association, DNA groove binding and electrostatic attraction [11]. In recent years, investigations of anticancer agents have resulted in the development of a large number of palladium complexes with nitrogen donor lignads, such as various alkyl and aryl substituted amines and imines, azo, hydrazo, pyridine and pyrimidine derivatives, some of which exhibit effective antitumor properties both in vivo and in vitro $[12,13]$. In the case of palladacycles, their intercalative mode cytotoxic action has been proven to be be strictly related to the presence of a planar and highly stable aromatic metallacycle $[14,15]$. It has also been reported that some cyclopalladated complexes containing planar structures, suchas aromatic and aliphatic amines, exhibit cytotoxic effects against some tumor cells producing intercalative lesion on DNA [16,17]. Since intercalation involves insertion of a planar aromatic molecule between two nucleotide base units, both these classes of compounds are good metallointercalators. On the other hand, coordination of phosphorus ligands to transition metals favors hydrophilicity and promotes interactions with DNA [18], leading to the enhancement of complex cytotoxicity. Importantly, ferrocene derivatives such as 1,1-bis(diphenylphosphine)ferrocene (dppf), ferrocifen, hydroxyferrocifen, ferrocephanes and ferroquine are well known for their potential anticancer and antimalarial activities, respectively [19,20,21,22,23,24,25,26]. Nevertheless, a recent breakthrough from Caires' group has shown that chiral cyclopalladated complexes derived from N,N-dimethyl-1-phenethylamine and the coordinating ligand dppf have promising non-cytotoxic anticancer activity. In vivo animal studies have shown that significant tumor shrinkage can be achieved and that very little toxicity is observed, even at high doses. The complexes were investigated as Cathepsin B inhibitors and antitumoral agents against solid tumors [27,28,29]. Moreover, investigation on the effect of metal ions on drugprotein binding is useful to understand the transport and mechanism of the drug in the body [30,31]. Serum albumin is the major soluble protein, which plays an important and efficient role in drug delivery due to its involvement in the circulatory system as well as reversibly binding properties with drugs and metal ions in the bloodstream [32,33]. With regards to these facts and in continuation of our ongoing research in the field of design and synthesis of cyclopoalladated complex antitumor agents [34,35,36,37], In this paper, we were encouraged to design, synthesize and fully characterize two new cyclometallating complexes (Scheme 1) and we have studied the ability of the complexes to interact with DNA and BSA. The cytotoxic activity of both complexes against two human cancer cell lines (JURKAT and SKOV3) was evaluated by MTT assay. To determine selective effect of complexes on cancer cells, normal PBMC cells were also 
treated under the same experimental conditions for cancer cells. Molecular docking technique was also used to determine the mechanism and interaction mode of the complexes towards DNA and BSA.

\section{Experimental}

2.1. Synthesis of compound (2) $\left[\mathbf{P d}_{2}\left\{(\mathbf{C}, \mathbf{N})-\mathbf{C}_{12} \mathbf{H}_{\mathbf{8}} \mathbf{N H}_{2}\right)\right\}_{2}(\boldsymbol{\mu}$-dppf $\left.) \mathbf{C l}_{2}\right]: 0.19 \mathrm{~g}$ of dppf $(0.35 \mathrm{mmol})$ was added to a suspension formed of $0.215 \mathrm{~g}(0.35 \mathrm{mmol})$ of cyclopalladated complex 1in dichloromethane $(20 \mathrm{~mL})$ (molar ratio 1:1). The reaction mixture was stirred for $5 \mathrm{~h}$ at room temperature and then filtered through a plug of $\mathrm{MgSO}_{4}$. Subsequently, the solvent was evaporated under reduced pressure to almost dryness and the reaction product was precipitated by the addition of $\mathrm{n}$-hexane. The resulting solid was filtered, washed with diethyl ether, and dried under vacuum. The complex obtained was isolated and characterized. Yellow solid (68.2\%).Anal. Calc. for $\mathrm{C}_{58} \mathrm{H}_{48} \mathrm{Fe}_{2} \mathrm{Cl}_{2} \mathrm{~N}_{2} \mathrm{P}_{2} \mathrm{Pd}_{2}$ : C 59.31; H 4.12; N 2.39\%. Found. C 58.81; H 3.85; N 2.05\%. IR (KBr pellet, $\left.\mathrm{cm}^{-1}\right): v_{\mathrm{a}}$ $\left(\mathrm{NH}_{2}\right)=3323, v_{\mathrm{s}}\left(\mathrm{NH}_{2}\right)=3247, v\left(\mathrm{C}-\mathrm{H}_{\mathrm{Ph}}\right)=3050, v(\mathrm{C}=\mathrm{C}$ aromatics $)=1437, v(\mathrm{Pd}-\mathrm{C})=693, v(\mathrm{Pd}-\mathrm{P})=523, v(\mathrm{P}-\mathrm{C})=$ 1165. ${ }^{1} \mathrm{H}$ NMR (400.13 MHz, $\left.\mathrm{CDCl}_{3}, \mathrm{ppm}\right): \delta=3.11\left(\mathrm{~S}, 1 \mathrm{H}, \mathrm{NH}_{2}\right), 3.64\left(\mathrm{~S}, 1 \mathrm{H}, \mathrm{NH}_{2}\right), 4.34\left(\mathrm{~S}, 1 \mathrm{H}, \mathrm{NH}_{2}\right), 4.41(\mathrm{~S}, 1 \mathrm{H}$, $\left.\mathrm{NH}_{2}\right)$, 4.05-4.21(m,4H, $\left.\mathrm{Fe}\left(\mathrm{C}_{5} \mathrm{H}_{4}\right)\right)$, 4.87-5.04 (m, $\left.4 \mathrm{H}, \mathrm{Fe}\left(\mathrm{C}_{5} \mathrm{H}_{4}\right)\right)$, 6.50-8.12 (m, 36H aromatic rings), $13 \mathrm{C}-\{1 \mathrm{H}\}$ $\left.\operatorname{NMR}\left(100.61 \mathrm{MHz}, \mathrm{CDCl}_{3}, \mathrm{ppm}\right) 75.79,76.35 \mathrm{Fe}\left(\mathrm{C}_{5} \mathrm{H}_{4}\right)\right), 119-139$ (aromatic rings). ${ }^{1} \mathrm{P}\{1 \mathrm{H}\} \mathrm{NMR}\left(\mathrm{CDCl}_{3}(\mathrm{ppm})\right.$ : $\delta=28.65(\mathrm{~S}), 29.01(\mathrm{~S}), 33.96(\mathrm{~S})$.

2.2. Synthesis of compound (3) $\left.\left[\mathbf{P d}_{2}\left\{(\mathbf{C}, \mathbf{N})-\mathbf{C}_{12} \mathbf{H}_{8} \mathbf{N H}_{2}\right)\right\}_{2}(\mu-d p p) C_{2}\right]$ : Compound 3 was prepared using the same procedure as described for 2 using $0.215 \mathrm{~g}(0.35 \mathrm{mmol})$ of cyclopalladated complex 1 and $0.069 \mathrm{~g}(0.35 \mathrm{mmol})$ of bpp. Gray solid (76\%).Anal. Calc. for $\mathrm{C}_{37} \mathrm{H}_{34} \mathrm{Cl}_{2} \mathrm{~N}_{4} \mathrm{Pd}_{2}$ : C 54.30; H 4.19; N 6.58\%. Found. C 53.24; H 3.91; N 6.12\%. IR $\left(\mathrm{KBr}\right.$ pellet, $\left.\mathrm{cm}^{-1}\right): v_{\mathrm{a}}\left(\mathrm{NH}_{2}\right)=3325, v_{\mathrm{s}}\left(\mathrm{NH}_{2}\right)=3243, v\left(\mathrm{C}-\mathrm{H}_{\mathrm{Ph}}\right)=3050, v(\mathrm{C}=\mathrm{C}$ aromatics $)=1437, v(\mathrm{Pd}-\mathrm{C})$ $=693 \mathrm{v}(\mathrm{Pd}-\mathrm{N})=523 .{ }^{1} \mathrm{H}$ NMR $\left(400.13 \mathrm{MHz}, \mathrm{CDCl}_{3}, \mathrm{ppm}\right): \delta=1.91-1.92\left(\mathrm{~m}, 2 \mathrm{H}, \mathrm{CH}_{2}\right), 2.61-2.68\left(\mathrm{~m}, 4 \mathrm{H}, \mathrm{CH}_{2}\right)$, $6.37\left(\mathrm{~S}, 1 \mathrm{H}, \mathrm{NH}_{2}\right), 6.39\left(\mathrm{~S}, 1 \mathrm{H}, \mathrm{NH}_{2}\right), 6.50\left(\mathrm{br} \mathrm{S}, 2 \mathrm{H}, \mathrm{NH}_{2}\right), 6.83-8.46\left(\mathrm{~m}, 24 \mathrm{H}\right.$ aromatic rings). ${ }^{13} \mathrm{C}-\{1 \mathrm{H}\}$ $\operatorname{NMR}\left(100.61 \mathrm{MHz}, \mathrm{CDCl}_{3}, \mathrm{ppm}\right) 29.10,29.55,33.63,120.82,123.91,123.95,124.11,124.25,124.82,124.97$, 125.29, 125.63, 126.60, 127.06, 127.34, 127.44, 127.50, 128.81, 128.87, 128.92, 135.44, 135.63, 135.70, 137.18, 137.28, 137.43, 137.60, 139.0, 139.12, 139.89, 149.49, 149.55, 150.05, 152.38, 152.48, 153.26, 153.41 .

\section{Scheme 1}

\subsection{Singlecrystal structure determination}

X-ray diffraction experiments were carried out at $100 \mathrm{~K}$ using an Agilent Super Nova single crystal diffractometer (Mo K(a) radiation). Analytical numeric absorption correction was made using a multi-faceted crystal model based on expressions derived by R.C. Clark \& J. S. Reid[38]. The structures were solved by direct methods using the 
SHELXS97 program and refined by SHELXL (Sheldrick 2008) program. Hydrogen atoms were added in the calculated positions and were riding on their respective carbonsduring the refinement.

\subsection{Molecular docking with DNA and BSA}

The crystallography information file (*.cif) of complex 1 was used for docking. Before the docking calculations, the geometry optimization was performed for complex 2 by DFT methods employing B3LYP functional [39]. The 6$31+\mathrm{G}(\mathrm{d}, \mathrm{p})$ basis set for $\mathrm{C}, \mathrm{N}, \mathrm{H}$, Cland Oand the Los Alamos effective core potential plus DZ basis set (LANL2DZ) for the Pd were employed. Gaussian 09 Quantum Chemistry package [40] was used for the optimization. The DNA sequence d(CGCGAATTCGCG)2 was taken from the Protein Data Bank (PDB ID: 3U2N) at a resolution of $1.25 \AA$. The structure of BSA was obtained from the Protein Data Bank (PDB ID: 4JK4) at a resolution of $2.65 \AA$ A. During the preparation of the DNA and BSA input files, chain (A) of BSA and all the hetero atoms including water molecules were removed. Docking calculations were performed by Auto Dock 4.2 package [41] using the Lamarckian genetic algorithm (LGA) [42].The blind docking was used [43,44] to find the suitable binding sites for the interaction of the complexes with DNA and BSA. After finding the best location by the blind docking, the focus docking was performed on the best location. The size of the grid map used for the docking were set to $70 \times 70 \times 70$ Å3. A gridpoint spacing of $0.375 \AA$ (roughly a quarter of the length of a carboncarbon single bond) were wasused for Auto Grid runs. The conformations were ranked based on the lowest free binding energy. The standard values were used for all docking parameters. Molegro Molecular Viewer (MMV) [45] and UCSF Chimera [46]packages were used to produce molecular images. The schematic twodimensional representations of the docking results were depicted using Discovery Studio Visualizer [47].

\subsection{Culture medium and cell lines}

JURKAT (human leukemic T cell), SKOV3 (human ovarian cancer cell line), and PBMC (peripheral blood mononuclear cells) cell lines were supplied from the National Cell Bank of Pasteur Institute, Tehran, Iran. Cells were cultured in Dulbecco's Modified Eagle Medium (DMEM) supplemented with 10\% heatinactivated fetal bovine serum (FBS), $100 \mathrm{U} \mathrm{mL}^{-1}$ penicillin, $100 \mu \mathrm{g} \mathrm{m}^{-1}$ streptomycin and $5 \mathrm{mM} \mathrm{L}^{-1}$ glutamine. Subsequently, the cell lines were grown at $37^{\circ} \mathrm{C}$ in a humidified atmosphere containing $5 \% \mathrm{CO}_{2}$. All reagents and cell culture media were purchased from Gibco Company (Germany).

\subsection{Cytotoxicity assay}

MTT [3-(4,5-dimethylthiazol-2-yl)-2,5-diphenyl-tetrazolium bromide] colorimetric assay was used to evaluate the cytotoxic activity of complexes 2 and 3 . This test is based on the metabolic reduction of soluble MTT by mitochondrial enzyme activity of viable tumor cells. The product is an insoluble colored formazan, which can be quantified spectrophotometrically after dissolution in dimethyl sulfoxide (DMSO). In order to perform the cytotoxicity assay, $200 \mu \mathrm{L}$ of cells $\left(5 \times 10^{4}\right.$ cells $\left.\mathrm{mL}^{-1}\right)$ were seeded in 96 well microplates and incubated for $24 \mathrm{~h}$ $\left(37^{\circ} \mathrm{C}, 5 \% \mathrm{CO}_{2}\right.$ air humidified). Subsequently, $20 \mu \mathrm{L}$ of prepared concentrations of each compound were added to the wells. The compounds were dissolved in DMSO before being added to the culture media. The negative control 
groups contained DMSO at the same concentration $[0.5 \%(\mathrm{v} / \mathrm{v})]$ as treated groups. Cisplatin, was used as the positive control. After $48 \mathrm{~h}$ of incubation, $20 \mu$ Lof MTT solution ( $5 \mathrm{mg} \mathrm{mL}^{-1}$ in phosphate buffer solution) were added and the plates were incubated for another $3 \mathrm{~h}$. $150 \mu$ Lof the medium containing MTT were then gently replaced by DMSO and pipetted to dissolve any formazan crystal formed. Absorbance was then determined at 560 $\mathrm{nm}$ using an ELISA plate reader (Awareness Technology Inc., Stat Fax 2100). Results were generated from three independent experiments and each experiment was performed in triplicate. $\mathrm{IC}_{50}$ (concentration which inhibits cell growth by 50\%) values of complexes 2 and 3 against each tested cell line were calculated using non-linear regression of concentration response curves. The selectivity index (SI) was also calculated based on the $\mathrm{IC}_{50}$ ratio of normal human peripheral blood mononuclear (PBMC) and cancer (JURKAT and SKOV3) cells. SI value indicates theselectivity of the sample to the cell lines tested. Samples with SI values greater than 2 were considered to be highly selective [48].

\section{Results and discussion}

\subsubsection{Description of molecular structure}

Complex 2 (Scheme 1) was found to be air stable both in solid form as well as in solution and soluble in common organic solvents. Suitable crystals of compound 2 were grown by slow evaporation of dichloromethane/n-hexane solutions. An ORTEP representation of 2 is shown in Figure 1. A summary of the crystal data is compiled in Table 1 .

The molecular structure of compound 2 shows dppf coordinating in the 'open-bridge' mode. There are rather frequent reports of dppf coordinating in this fashion, where thedppfligand bridges between two $\mathrm{M}$ fragments [49].A phosphorus atom from the diphosphine ligand, which bridges the two metal atoms, completes the metal coordination sphere. The Pd1...Pd2 distance is 8.095 Á, showing that the two metal atoms in the dimer are not directly bonded. As it can be observed in the molecular structure, the symmetric bidentate phosphine bridges the two palladium(II) centers and is coordinated to the cyclopalladated units in a trans- $N, P$ stereochemistry. The square planar coordination geometry of the palladium(II) metal is slightly distorted and the bond angles around the Pd center range from 75 to $85^{\circ}$. The chelating C-N bite angle, i.e., C30-Pd1-N2, amounts to 83.46(14), which is significantly smaller than $90^{\circ}$, suggesting a rigid "bite" angle of the chelating ligand. The Cp (centroid) …Fe...Cp (centroid) twist angle of dppf is $126^{\circ}$ (the angle has been determined as the torsion angle $\mathrm{C} 14 \cdots \mathrm{Cp} 1$ (centroid) $\cdots \mathrm{Cp} 2$ (centroid) ... 18 , and thus dppf is arranged close to the "anticlinal eclipsed" or "anticlinal staggered" conformation [50]. The ideal torsion angle for this conformation is $144^{\circ}$.

The molecular packing diagram analysis of the complex reveals that the stabilization of the lattice is governed by

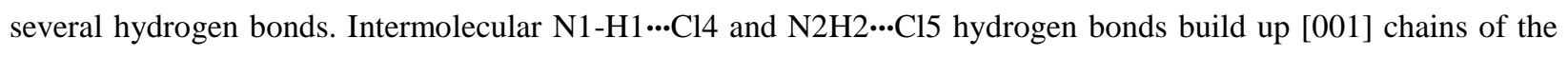
neighboring molecules, which are reinforced by $\mathrm{C}-\mathrm{H} \cdots \pi$ interactions $\left(\mathrm{C} 13-\mathrm{H} 13 \cdots \mathrm{Cg}: d_{\mathrm{H} \cdots \mathrm{Cg}}=2.82 \AA ⿻ d_{\mathrm{C} \cdots \mathrm{Cg}}=\right.$ $3.478(4) \AA, \theta=124^{\circ},\left(\mathrm{C} 35-\mathrm{H} 35 \cdots \mathrm{Cg}: d_{\mathrm{H} \cdots \mathrm{Cg}}=2.89 \AA, d_{\mathrm{C} \cdots \mathrm{Cg}}=3.731(5) \AA, \theta=148^{\circ}\right.$; where $\mathrm{Cg}$ is the centroid center of 1(C13-C15) and 9(C35-C39) ring, respectively) Figure 2. On the other hand, the H-bonded chains link via other C$\mathrm{H} \cdots \pi$ interactions $\left(\mathrm{C} 4-\mathrm{H} 4 \cdots \mathrm{Cg}: d_{\mathrm{H} \cdots \mathrm{Cg}}=2.97 \AA, d_{\mathrm{C} \cdots \mathrm{Cg}}=3.812(5) \AA, \theta=149^{\circ}\right.$, where $\mathrm{Cg}$ is the centroid of 5(C1-C6) 
ring), leading to the formation of 2D (110) layers Figure 3.In this structure, the interacting solvent moleculescontribute to furtherstabilization of the crystal packing.Dichloromethane atoms are involved in

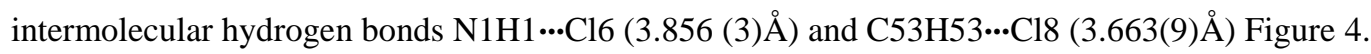

\section{Scheme 2}

Figure 1

Figure 2

Figure 3

Figure 4

\subsubsection{NMR spectroscopy}

Formation of complexes 2 and 3 is further supported by detection of peaks in NMR spectra. ${ }^{1} \mathrm{H},{ }^{31} \mathrm{P}$ and ${ }^{13} \mathrm{C}$ NMR spectral data of the complexes are given in Figure S1-S5 in the Supporting Information. ${ }^{1} \mathrm{H}$ NMR spectra of complexes 2 and 3 show that these compounds represent a molecular structure with an apparent center of inversion, which divides the molecules into two symmetrical parts. This is in agreement with the structures proposed for these compounds with symmetric dppf,and bpp ligands:i) bridging the two palladium (II) centers and ii) coordination to the cyclopalladated units with trans- $N, P$ stereochemistry. The ${ }^{1} \mathrm{H}$ NMR spectrum of complex 2 shows singlets at $3.11,3.64,4.34$, and $4.41 \mathrm{ppm}$ of the $\mathrm{NH}_{2}$ proton groups resonated separately, indicating that the protons are located in different environments. Two apparent multiplets at 4.05-4.21 and 4.87-5.04 ppm associated with $\mathrm{C}_{5} \mathrm{H}_{4}$ ring protons constitute an $\mathrm{AA}^{\prime} \mathrm{XX}$ 'spin system [51] and the multiplet in the range of 6.50-8.12 ppm is attributed to the aromatic protons. In the ${ }^{13} \mathrm{C}$ NMR spectrum of the ferrocenyl $(\mathrm{Cp})$ ring, signals appear in the 75.79-76.35 ppm range[52].As expected, aromatic carbon atoms show signals in 119-139 ppm range. The ${ }^{31} \mathrm{P}$ NMR spectrum shows three singlets at 28.65, 29.01 and $33.96 \mathrm{ppm}$. When asolid crystalline sample of complex 2, with its "anticlinal eclipsed" or "anticlinal staggered "conformation [50] is dissolved in asolvent, a fluxionality of the type shown in Scheme 2, probably occurs. As such, at room temperature the fluxionality behavior takes place very fast so that on average,the "antiperiplanar staggered" conformation, with an ideal torsion angle of $180^{\circ}$, is observed. This gives rise to the observation of a sharp singlet in the ${ }^{31} \mathrm{P}$ NMR spectrum. Furthermore, the ${ }^{1} \mathrm{H}$ NMR spectrum of complex 3 shows two multiplet sets of the aliphatic resonances for $\mathrm{CH}_{2}$ groups in the bbp bridge ligand at 1.91 and $2.61 \mathrm{ppm}$, respectively. Singlets at $6.37,6.39$, and $6.50 \mathrm{ppm}$ of the $\mathrm{NH}_{2}$ proton groups resonated separately and a multiplet in the range of 6.83-8.46 ppm, are associated with the aromatic protons. The ${ }^{13} \mathrm{C}\{1 \mathrm{H}\}$ NMR spectrum reveals the resonance for the aliphatic carbon atom of the bpp bridgegroup at 29.10, 29.55 and $33.63 \mathrm{ppm}$ and aromatic carbon atoms show signals in 120.82-153.41 ppm range.

\subsection{Nucleic acid binding}




\subsubsection{Absorption spectral characteristics of DNA binding}

Electronic absorption spectroscopy is a simple and reliable method to determine the binding affinity of metal complexes with DNA, as binding to the macromolecule leads to changes in the electronic spectra of the same[53]. In general, hyperchromism and hypochromism are the spectral features of DNA with regards to the changes of its double helix structure [54]. On account of the $\pi-\pi^{*}$ stacking interactions between the aromatic chromophore of the complex and the DNA helical basepairs, hypochromism and bathochromic shifts of the transition of the intercalated chromophore occur[55]. The extent of hypochromism is commonly consistent with the strength of intercalative interaction [56,57]. Therefore, the typical titration curves for the complexes in the absence and presence of CT-DNA at different concentrations were implemented and the results are shown in Figure S6 in the Supporting Information. Electronic spectra of complexes 2 and 3 show absorption peaks at 211 and $228 \mathrm{~nm}$, respectively. The bands appearing in the range of 211-228 $\mathrm{nm}$ are assigned to intraligand charge transfer (ILCT) and $\pi-\pi^{*}$ transition. Upon incremental additions of CT-DNA to the complexes, the $\pi \rightarrow \pi^{*}$ absorption bands of the complexes exhibit red shift and significant hypochromism of about 30.3 and $11.2 \%$ for complexes 2 and 3, respectively. Which indicates that the $\pi^{*}$ orbital of the intercalated complexes is coupled with that of the base pairs [58].

In order to elucidate the binding strength of the complexes with DNA, the binding constant, $\mathrm{K}_{\mathrm{b}}$, was determined using the following equation [59]:

$\frac{[\mathrm{DNA}]}{\left(\varepsilon_{\mathrm{a}}-\varepsilon_{\mathrm{f}}\right)}=\frac{[\mathrm{DNA}]}{\left(\varepsilon_{\mathrm{b}}-\varepsilon_{\mathrm{f}}\right)}+\frac{1}{\mathrm{~K}_{\mathrm{b}}\left(\varepsilon_{\mathrm{b}}-\varepsilon_{\mathrm{f}}\right)}(1)$

The absorption coefficients, $\varepsilon_{\mathrm{a}}, \varepsilon_{\mathrm{f}}$, and $\varepsilon_{\mathrm{b}}$, correspond to $\mathrm{A}_{\mathrm{obs}} /[\mathrm{DNA}]$, the extinction coefficient for the free complex and the extinction coefficient for the complex in the fully bound form, respectively. In particular, $\varepsilon_{\mathrm{f}}$ was determined by a calibration curve of the isolated Pd(II) complexes in an aqueous solution, following Beer's law. A plot of [DNA] $]\left[\varepsilon_{\mathrm{a}}-\varepsilon_{\mathrm{f}}\right]$ versus [DNA] gave a slope and an intercept equal to $1 /\left[\varepsilon_{\mathrm{a}}-\varepsilon_{\mathrm{f}}\right]$ and $1 / \mathrm{K}_{\mathrm{b}}\left[\varepsilon_{\mathrm{b}}-\varepsilon_{\mathrm{f}}\right]$, respectively (Figure. 2 , inset) [60]. Intrinsic binding constant, $\mathrm{K}_{\mathrm{b}}$, values of $2.32 \times 10^{5}$ for 2 and $1.11 \times 10^{5}$ for 3 were obtained following the above equation. Complex 2 binds more strongly than complex 3. This may be due to the intercalation of planar heterocyclic ring and bulky ferrocenyl group between the planes of DNA nucleic bases, therewithmore surface area of aromatic (Cp) moiety is present in complex 2, which enhances the extent of binding with DNA base pairs[21,61]. Furthermore, hydrogen bonding is also possible in the interaction of DNA with complexes, even though it is a weak interaction. DNA possesses several hydrogen bonding sites in the major as well as minor grooves. Since complexes contain amine $\mathrm{NH}$ groups, there could be hydrogen bonding between complexes and insertion of base pairs in DNA[62]. This $\mathrm{K}_{\mathrm{b}}$ value is similar to those reported for typical classical intercalators, such as methylene blue with CT-DNA $\left(3.3 \times 10^{5} \mathrm{M}^{-1}\right)$, proflavin with Escherichia coli DNA $\left(4.1 \times 10^{5} \mathrm{M}^{-1}\right)$, EB (Ethidium bromide) $\left(1.23 \times 10^{5}\right.$ $\left.\mathrm{M}^{-1}\right)$, indicating a strong binding to CT-DNA[63,64]. From the values of the binding constant $\left(\mathrm{K}_{\mathrm{b}}\right)$, free energy $(\Delta \mathrm{G})$ of the compound-DNA complex was calculated using equation (2):

$\Delta \mathrm{G}=-\mathrm{RT} \ln \mathrm{K}_{\mathrm{b}}$ 
Binding constants are a measure of the compound-DNA complex stability while the free energy indicates the spontaneity/non-spontaneity of compound-DNA binding. Free energies of complexes 2 and 3 were evaluated as -7.31 and $-6.88 \mathrm{kcal} \mathrm{mol}^{-1}$, respectively, showing the spontaneity of compound-DNA interaction.

\subsubsection{Competitive DNAbinding studies}

Luminescence property has not been observed for the complexes at room temperature in aqueous solutions and in any organic solvent, or in the presence of nucleic acids. Therefore, the binding of the complexes with DNA could not be directly predicted through emission spectroscopy. Hence, a competitive methylene blue (MB) DNA binding

study was undertaken to understand the mode of DNA interaction of the Pd(II) complexes $[65,66,67]$. Methylene blue (MB) is a planar cationic dye, which is widely used as a sensitive fluorescence probe for native DNA. MB emits intense fluorescent light in the presence of DNA due to its strong intercalation between adjacent DNA base pairs [68]. It has been previously reported that the fluorescence intensity of MB-DNA system is increased by adding certain complexes $[69,70,71]$. This indicates that the complexes are bound to the base pairs of DNA by intercalation mode while replacing the MB. In our experiments, as illustrated in Figure 3, the fluorescence intensities of MB bound to CT-DNA at $685 \mathrm{~nm}$ show remarkable increasing trends with the addition of concentration of the complexes, indicating that some MB molecules are released into the solution after the exchange with the complexes, resulting in the fluorescence enhancement of MB. Figure S7 in the Supporting Information clearly reveals the increase in the fluorescence intensity of the probe molecule (MB) ([DNA]/[MB]=10) by adding the $\operatorname{Pd}(\mathrm{II})$ complexes ([complex]/[DNA]=2.5). Thus, the experiments confirm that the interaction between DNA and $\operatorname{Pd}(\mathrm{II})$ complexes is the intercalation interaction.

\subsubsection{Helix melting experiment}

The study on the melting or thermal denaturation of nucleic acids plays an important role in the understanding the mode of DNA interaction with the transition metal complexes [72]. Denaturation of nucleic acids is induced by reducing the interactions within the double strand structures to separate into two single strands. The melting of DNA can be used to distinguish those molecules, which bind via intercalation and groove mechanism. In the presence of metallo-intercalators, Tm rises sharply until all the intercalating sites are saturated, after which the stabilization is due to electrostatic binding and $\mathrm{Tm}$ increases less steeply [73,74]. The helix melting experiment carried out for DNA in the absence of the $\mathrm{Pd}(\mathrm{II})$ complexes revealed a $\mathrm{Tm}$ of $85.56 \pm 0.2^{\circ} \mathrm{C}$ under our experimental conditions. However, with addition of $\mathrm{Pd}(\mathrm{II})$ complexes, the Tm of the DNA increases dramatically to $91.87 \pm 0.3^{\circ} \mathrm{C}$ for complex 2 and $90.51 \pm 0.3^{\circ} \mathrm{C}$ for complex 3 at a [Complex]/[DNA] ratio of 1:2, respectively Figure 5. The large increases in Tm of DNA with two complexes (the $\Delta \mathrm{T}_{\mathrm{m}}$ is 6.08 and $4.72^{\circ} \mathrm{C}$ for 2 and 3, respectively) are comparable to those observed for classical intercalators $[75,76]$.

Figure 5 


\subsection{Protein binding studies}

\subsubsection{Absorption spectral studies}

UV-Vis absorption spectroscopy is also a simple and applicable technique to explore the structural changes of proteins due to interaction with a drug or transition metal complexes [77]. Supporting Information, Figure S8 shows the UV-Vis absorption spectra of BSA in the presence of various concentrations of the two complexes. As observed in this figure, BSA has two absorption peaks. The strong absorption peak in the range of 220-240 nm reflects the framework conformation of the protein ( $\alpha$-helix structure) and the weak absorption peak at about $280 \mathrm{~nm}$ appears to be due to the aromatic amino acids (Trp, Tyr, and Phe) [78]. The figure also indicates that upon addition of the Pd complexes, the BSA skeleton absorption intensity in the range of $220-240 \mathrm{~nm}$ decreases due to the perturbation of the secondary structure of the protein $[79,80]$ and a subtle change on the maximum absorption at $280 \mathrm{~nm}$, which indicates a perturbation of $\alpha$-helix induced by a specific interaction between complexes and BSA [81].

\subsubsection{Binding affinity and binding site number by fluorescence spectroscopy}

Fluorescence spectra are useful in the qualitative analysis of the binding of transition metal complexes to BSA. Generally, the fluorescence of a protein is caused by three intrinsic components, namely Trp-134 located on the surface of domain I, Trp-213 located within the hydrophobic pocket of domain II, tyrosine and phenylalanine residues. The solutions of BSA exhibit a strong fluorescence emission band at $343 \mathrm{~nm}$, due to the tryptophan residues, when excited at $295 \mathrm{~nm}$. Binding of the complexes to BSA results in some conformational changes of the protein. These changes influence the fluorescence emission of tryptophan residues [82]. The interaction with BSA was monitored by the quenching of tryptophan fluorescence upon the addition of metal complexes Figure 6. Addition of metal complexes to the solution of BSA resulted in the quenching of its fluorescence emission without any shift, suggestinga change in protein secondary structure and configuration leading to changes in tryptophan environment of BSA and thus indicating the binding of all complexes to the serum albumins [83]. Fluorescence quenching is described by the Stern-Volmer equation (3)

$\mathrm{I}_{0} / \mathrm{I}=1+\mathrm{K}_{\mathrm{sv}}[\mathrm{Q}]=1+\mathrm{K}_{\mathrm{q}} \tau_{0}[\mathrm{Q}]$

where I and I0 are the fluorescence intensities of BSA with and without quencher (metal complex), respectively. $\mathrm{K}_{\mathrm{q}}$, $\mathrm{K}_{\mathrm{SV}}, \tau_{0}$ and $[\mathrm{Q}]$ are the quenching rate constants of the biomolecule, the dynamic quenching constant, the average lifetime of the biomolecule without quencher and the concentration of quencher, respectively. In the present work, the value of $\mathrm{K}_{\mathrm{sv}}$ values for complexes 2 and 3 are $5.4 \times 10^{4}$ and $8.3 \times 10^{4} \mathrm{M}^{-1} \mathrm{~s}^{-1}$ at $298 \mathrm{~K}$, respectively. These constants indicate good BSA binding affinity of the two complexes, exhibiting a high proteinbinding ability. The calculated values of $\mathrm{k}_{\mathrm{q}}$ for 2 and 3 are $2.70 \times 10^{12}$ and $4.18 \times 10^{12} \mathrm{M}^{-1} \mathrm{~s}^{-1}$, respectively, which are higher than $2 \times 10^{10} \mathrm{M}^{-1} \mathrm{~s}^{-1}$, the maximum scatter collision quenching constant of quenchers with BSA[84]. Thus, the rate constant calculated by protein quenching procedure is greater than $\mathrm{K}_{\mathrm{q}}$ of scatter procedure. This indicates that a static quenching mechanism is operative [85]. 
For the static quenching interaction, if it is assumed that there are similar and independent binding sites in the biomolecule, the binding constant $\left(\mathrm{K}_{\mathrm{a}}\right)$ and the number of binding sites (n) can be calculated from the following equation [84]:

$\log \frac{\left(I_{0}-I\right)}{I}=\log K_{a}+n \log [Q](4)$

where, $\mathrm{n}$ is the average number of binding sites per albumin molecule and $\mathrm{K}_{\mathrm{b}}$ is the binding constant for the complex protein interaction. The double logarithmic plot of $\log \left[\mathrm{I}_{0}-\mathrm{I} / \mathrm{I}\right]$ vs. $\log [\mathrm{Q}]$ is shown in the Supporting Information Figure S9. For the system containing complexes and BSA, the obtained values of $K_{a}$ and $n$ at $298 \mathrm{~K}$ were $5.1 \times 10^{4} \mathrm{M}^{-1}$ and 1.08 for 2 and $6 \times 10^{4} \mathrm{M}^{-1}$ and 1.3 for 3, respectively. Moreover, the linear correlation coefficient was calculated to be 0.997 , which indicates that the assumptions underlying the derivation of equation (4) were satisfied. Complex 3 exhibits a higher binding constant for BSA than the other, while complex 2 exhibits a lower $\mathrm{K}$ value, which may be attributed to large steric effects. Furthermore, $n$ equivalent to 1 or $(n<1)$ forcompound-BSA complex 2 implies only a binding site per albumin, whereas there are more binding sites on BSA for complex $3(n>1)$.

\section{Figure 6}

\subsubsection{Site selective binding}

The tertiary structure of BSA is composed of three homologous $\alpha$-helices in domains (I-III) and each domain includes two sub-domains called A and B to form a cylinder[86]. On the basis of the probe displacement method, there are at least three major specific drugbinding sites on the serum albumin molecules. These sites, commonly called Eosin Y (EY) and Warfarin (WF), Ibuprofen (IB) and Fluofenamic acid (FA), and Digoxinbinding sites, are also denoted as sites I, II, and III, respectively $[87,88,89]$. In this work, in order to identify the metal complex binding sites on BSA, site marker competitive experiments were carried out, using metal complexes (Warfarin/Ibuprofen/Digoxin), which specifically bind to a known site or region on BSA. Information on the binding site to which the metal complexes bind can be obtained by monitoring the changes of the fluorescence of BSA after binding with the complex in the presence of site marker. As shown in Figure 7A-C, with the addition of site marker (Warfarin/Ibuprofen/Digoxin) into BSA, the fluorescence intensity becomes lower than that without the site marker. To facilitate the comparison of the influence of Warfarin, Ibuprofen and Digoxin on the binding of complexes to BSA, the binding constant in the presence of site markers was analyzed using equation (4) (Table 2). The binding constant is surprisingly variable in the presence of Warfarin, while a smaller influence is observed in the presence of Ibuprofen and Digoxin (somewhat lower than that with isolated BSA). The results indicate that the binding binding sites for complexes 2 and 3 are mainly located within site I of BSA.

Figure 7 


\subsection{Molecular docking of the complexes with DNA and BSA}

In this study, molecular docking calculations were employed to investigate the interaction of complexes with DNA and BSA. Molecular docking techniques are welldocumented computational tools to suggest the most acceptable mechanism for intermolecular interaction of the drug with biomolecules. The calculated free binding energies $\left(\Delta G_{\mathrm{b}}\right)$ of the interaction of complexes 2 and 3 with DNA and BSA are tabulated in Table 2. Figure 8(A) demonstrates the structure of complex 2+ DNA system obtained from docking calculation. The interactions between the complex 2 atoms and DNA residues generated by Discovery Studio Visualizer, are depicted in Figure 8 (B). The binding free energy for the complex 2 was found to be $-7.62 \mathrm{kcal} \mathrm{mol}^{-1}$. The structure of complex 3+ DNA system and the interactions between the complex 3 atoms and DNA residues are demonstrated in Figures 9 (A) and (B),respectively. The binding free energy for the complex 3 was found to be $-8.24 \mathrm{kcal} \mathrm{mol}^{-1}$. The results of docking model revealed that the complexes interact with DNA through intercalation mode. In Figure 10, the structure of complex 2+ BSA system and the interactions between the complex 2 atoms and the binding sites of BSA are shown. As shown in the Figure 10 (B), the residues involved in the interaction of the complex 2 with BSA are Glu291, Asp450, Arg217, Diu604, Glu443, Lys221, Lys294, Cys447 and Arg435. The binding free energy for the complex 2 to BSA was found to be $-6.29 \mathrm{kcal} \mathrm{mol}^{-1}$. The docking study shows that the distance between the Trp213 residue and the complex 2 is $2.6 \AA$. Figure 11 shows the structure of complex 3+ BSA system and the interactions between the complex 3 atoms and BSA binding sites. The binding free energy for the complex to BSA was found to be -9.62 $\mathrm{kcal} \mathrm{mol}^{-1}$. According to the result of docking study, the distance between the Trp213 residue and the complex 3 is 5.9 $\AA$ and the residues involved in the interaction of the complex 3 with BSA are Ala290, Glu291, Arg194, Lys221, Arg217, Lys439, Glu443 and Cys447.

\section{Figure 8-9}

\section{Figure 10-11}

\subsection{In vitro selective cancercell cytotoxic activity}

The in vitro cytotoxic activity of complexes 2 and 3 against human leukemic T cell (JURKAT), human ovarian cancer (SKOV3) cell lines, and normal PBMC cells $48 \mathrm{~h}$ after the treatment were evaluated by MTT-dye reduction method, as a wildly used bioassay[90,91,92]. As illustrated in Figure 12, the dose-dependent reduction in the survivability of JURKAT and SKOV3 cancer cells treated by complex 2 ranged from 14 to $84 \%$ and 45 to $93 \%$, and for complex 3, it ranged from 8 to $71 \%$ and 32 to $84 \%$, respectively. Both complexes revealed high cytotoxicity against JURKAT and SKOV3 cancer cells, and were even more active than cisplatin drug Table 3. Thus, complex 3 wascytotoxic against JURKAT and SKOV3 cancer cell lines with $\mathrm{IC}_{50}$ values of 5.2 and $2.3 \mu \mathrm{M}$, respectively. Higher cytotoxicity was observed on both cancer cells when treated by complex 2, as $\mathrm{IC}_{50}$ values of this complex on JURKAT and SKOV3 cancer cell lines were 6.7 and $5.7 \mu \mathrm{M}$, respectively. Both complexes 2 and 3 exhibited low cytotoxic activity against normal cells with $\mathrm{IC}_{50}$ values of 39 and $31 \mu \mathrm{M}$, respectively Table 3 . The trusty of our The 
validity of our results is confirmed by the numerous in vivo and in vitro studies that have evaluated cytotoxicity of cyclopalladated complexes against cancer cells [5,16,27,34]. For instance, in vitro studies by Kazem Karami et al. showed that palladacyclic complexes possessed high cytotoxicity ( $\mathrm{IC}_{50}<10 \mu \mathrm{M}$ ) against a panel of solid tumour cell lines, such as breast cancer MCF-7 cell line [34] Noticeable cytotoxic activity of complexes 2 and 3 is related to their structure. The presence of nitrogen donor ligand and a planar and highly stable aromatic metallacycle in both complexes lead to their interaction with DNA molecules, which result in inhibitory effect on cell cycle and growth $[16,17,18]$. As revealed in Table 3, SI values of both complexes were found to be higher than 2, which in term of SI definition [48], are imputed as the selective. Our results are also in good correlation with the previous studies in which more cytotoxic activity to cancer cells than the normal cells $[90,93,94,95,96,97]$ was found, owing to the sensitivity of cancer cells towards the death complexes. Consequently, both complexes, 2 being more active than 3 , exhibited significant selective dose-dependent inhibition on proliferation and viability of both cancer cells.

\section{Conclusion}

The present article embodies the synthesis of two new complexes of formula $\left.\left[\mathrm{Pd}_{2}\left\{(\mathrm{C}, \mathrm{N})-\mathrm{C}_{12} \mathrm{H}_{8} \mathrm{NH}_{2}\right)\right\}_{2}(\mu-\mathrm{dppf}) \mathrm{Cl}_{2}\right]$ $\left[\mathrm{Pd}_{2}\left\{(\mathrm{C}, \mathrm{N})-\mathrm{C}_{12} \mathrm{H}_{8} \mathrm{NH}_{2}\right)\right\}_{2}(\mu$-dpp $\left.) \mathrm{Cl}_{2}\right]$ and their characterization by analytical, spectroscopic and single crystal X-ray diffraction studies in order to evaluate their biological applications. Initially, the binding behaviors of the complexes with nucleic acids and Bovine Serum Albumin have been investigated using absorption and fluorescence spectroscopic techniques. The intercalation of the diphenylphosphine moiety and the hydrophobic interaction of the amine ligands confer enhanced DNA binding affinity upon the Pd(II) complexes, which is supported by the highest increment in emission intensity of DNA bound MB and the enhancement in relative helix melting of DNA upon binding to the complexes. The BSAbinding studies revealed that both $\mathrm{Pd}(\mathrm{II})$ complexes bind to protein BSA responsible for quenching of tryptophan fluorescence by the static quenching mechanism. The site marker displacement experiments suggested the site of the complexes binding to BSA was Sudlow's site I. Further docked models also confirmed the binding affinity of the complexes with DNA and BSA. Notably, the complexes exhibited significant in vitro selective cytotoxicity against two human cancer cell lines (JURKAT and SKOV3). There is a correlation between the DNA binding and cytotoxicity of the complexes proving complex 2 to be a better candidate as an anticancer drug. Further studies on the palladium complexes in vivo anticancer activities are currently in progress in our research group.

\section{Acknowledgements}

This study was funded and supported by Isfahan University of Technology. We gratefully thank the Iran National Science Foundation (INSF) for their financial support. Crystallography was provided by Institute of Physical Chemistry, Polish Academy of Sciences, Warsaw, Poland. 


\section{References}

[1] C.S. Allardyce, A. Dorcier, C. Scolaro, P.J. Dyson, Development of organometallic (organo- transition metal) pharmaceuticals, Appl. Organomet. Chem. 19 (2005) 1-10.

[2] J. Dupont, C.S. Consorti, J. Spencer, The potential of palladacycles: more than just precatalysts, Chem. Rev. 105 (2005) 2527-2572.

[3] C. Navarro- Ranninger, I. LóPez- Solera, J. Pérez, J. Masaguer, C. Alonso, In vitro antitumour activity of two isomeric cyclopalladiated compounds derived from benzoylbenzylidenimines, Appl. Organomet. Chem. 7 (1993) 57-61.

[4] J.D. Higgins, L. Neely, S. Fricker, J. Matthey, Synthesis and cytotoxicity of some cyclometallated palladium complexes, J. Inorg. Biochem. 49 (1993) 149-156.

[5] C. Navarro-Ranniger, I. Lopez-Solera, J.M. Perez, J. Rodriguez, J.L. Garcia-Ruano, P.R. Raithby, J. Masaguer, C. Alonso, Analysis of two cycloplatinated compounds derived from N-(4-methoxyphenyl)-. alpha.benzoylbenzylidenamine. Comparison of the activity of these compounds with other isostructural cyclopalladated compounds, J. Med. Chem. 36 (1993) 3795-3801.

[6] A.C.F. Caires, E.T. Almeida, A.E. Mauro, J.P. Hemerly, S.R. Valentini, Synthesis and cytotoxicity of some cyclometallated palladium (II) complexes containing coordinated azide and diphosphines, Quimica Nova 22 (1999) 329-334.

[7] Y.-M. Song, Q. Wu, P.-J. Yang, N.-N. Luan, L.-F. Wang, Y.-M. Liu, DNA Binding and cleavage activity of Ni (II) complex with all-trans retinoic acid, J. Inorg. Biochem. 100 (2006) 1685-1691.

[8] C. Tan, J. Liu, L. Chen, S. Shi, L. Ji, Synthesis, structural characteristics, DNA binding properties and cytotoxicity studies of a series of Ru (III) complexes, J. Inorg. Biochem. 102 (2008) 1644-1653.

[9] G. Zuber, J.C. Quada, S.M. Hecht, Sequence selective cleavage of a DNA octanucleotide by chlorinated bithiazoles and bleomycins, J. Am. Chem. Soc. 120 (1998) 9368-9369.

[10] S.M. Hecht, Bleomycin: new perspectives on the mechanism of action 1, J. Nat. Prod. 63 (2000) 158-168.

[11] G. Onoa, V. Moreno, E. Freisinger, B. Lippert, Pd (II)-and Pt (II)-cimetidine complexes. Crystal structure of trans-[Pt (N, S-cimetidine) 2] Cl 2. 12H 2 O, J. Inorg. Biochem. 89 (2002) 237-247.

[12] L. Giovagnini, L. Ronconi, D. Aldinucci, D. Lorenzon, S. Sitran, D. Fregona, Synthesis, characterization, and comparative in vitro cytotoxicity studies of platinum (II), palladium (II), and gold (III) methylsarcosinedithiocarbamate complexes, J. Med. Chem. 48 (2005) 1588-1595.

[13] J. Ruiz, N. Cutillas, C. Vicente, M.D. Villa, G. López, J. Lorenzo, F.X. Avilés, V. Moreno, D. Bautista, New palladium (II) and platinum (II) complexes with the model nucleobase 1-methylcytosine: antitumor activity and interactions with DNA, Inorg. Chem. 44 (2005) 7365-7376.

[14] A. Crispini, M. Ghedini, Five-membered cyclopalladated rings: Cambridge structural database analysisof geometrical parameters and 'aromatic'character, J. Chem. Soc., Dalton Trans. (1997) 75-80.

[15] M. Ghedini, I. Aiello, A. Crispini, A. Golemme, M. La Deda, D. Pucci, Azobenzenes and heteroaromatic nitrogen cyclopalladated complexes for advanced applications, Coord. Chem. Rev. 250 (2006) 1373-1390.

[16] C. Navarro-Ranninger, I. López-Solera, V.M. González, J.M. Pérez, A. Alvarez-Valdés, A. Martín, P.R. Raithby, J.R. Masaguer, C. Alonso, Cyclometalated Complexes of Platinum and Palladium with N-(4Chlorophenyl)- $\alpha$-benzoylbenzylideneamine. In Vitro Cytostatic Activity, DNA Modification, and Interstrand Cross-Link Studies, Inorg. Chem. 35 (1996) 5181-5187.

[17] F. Zamora, V.M. González, J.M. Pérez, J.R. Masaguer, C. Alonso, C. Navarro- Ranninger, Pd (II) and Pt (II) Complexes of 2- Phenyl- and 2- Benzyl- imidazoline: Synthesis, Structural Characterization, DNA Modification and in vitro Antileukaemic Activity, Appl. Organomet. Chem. 11 (1997) 659-666.

[18] M. Peruzzini, L. Gonsalvi, Phosphorus Compounds: Advanced Tools in Catalysis and Material Sciences, Springer Science \& Business Media, 2011.

[19] G. Gasser, I. Ott, N. Metzler-Nolte, Organometallic anticancer compounds, J. Med. Chem. 54 (2010) 3-25.

[20] R.H. Fish, G. Jaouen, Bioorganometallic chemistry: structural diversity of organometallic complexes with bioligands and molecular recognition studies of several supramolecular hosts with biomolecules, alkalimetal ions, and organometallic pharmaceuticals, Organometallics. 22 (2003) 2166-2177.

[21] C. Ornelas, Application of ferrocene and its derivatives in cancer research, New J. Chem. 35 (2011) 1973-1985.

[22] A. Nguyen, A. Vessières, E.A. Hillard, S. Top, P. Pigeon, G. Jaouen, Ferrocifens and ferrocifenols as new potential weapons against breast cancer, CHIMIA. 61 (2007) 716-724.

[23] P. Messina, E. Labbé, O. Buriez, E.A. Hillard, A. Vessières, D. Hamels, S. Top, G. Jaouen, Y.M. Frapart, D. Mansuy, Deciphering the activation sequence of ferrociphenol anticancer drug candidates, Chem. Eur. J. 18 (2012) 6581-6587. 
[24] D. Hamels, P.M. Dansette, E.A. Hillard, S. Top, A. Vessières, P. Herson, G. Jaouen, D. Mansuy, Ferrocenyl quinone methides as strong antiproliferative agents: formation by metabolic and chemical oxidation of ferrocenyl phenols, Angew. Chem. Int. Ed. 48 (2009) 9124-9126.

[25] E.A. Hillard, G. Jaouen, Bioorganometallics: Future Trends in Drug Discovery, Analytical Chemistry, and Catalysis $\dagger,+$, Organometallics 30 (2011) 20-27.

[26] C. Biot, G. Glorian, L.A. Maciejewski, J.S. Brocard, O. Domarle, G. Blampain, P. Millet, A.J. Georges, H. Abessolo, D. Dive, Synthesis and antimalarial activity in vitro and in vivo of a new ferrocene-chloroquine analogue, J. Med. Chem. 40 (1997) 3715-3718.

[27] C. Bincoletto, I.L. Tersariol, C.R. Oliveira, S. Dreher, D.M. Fausto, M.A. Soufen, F.D. Nascimento, A.C. Caires, Chiral cyclopalladated complexes derived from N, N-dimethyl-1-phenethylamine with bridging bis (diphenylphosphine) ferrocene ligand as inhibitors of the cathepsin B activity and as antitumoral agents, Bioorg. Med. Chem. 13 (2005) 3047-3055.

[28] C.M. Barbosa, C.R. Oliveira, F.D. Nascimento, M.C. Smith, D.M. Fausto, M.A. Soufen, E. Sena, R.C. Araújo, I.L. Tersariol, C. Bincoletto, Biphosphinic palladacycle complex mediates lysosomal-membrane permeabilization and cell death in K562 leukaemia cells, Eur. J. Pharmacol. 542 (2006) 37-47.

[29] A.C. Caires, Recent advances involving palladium (II) complexes for the cancer therapy, Anticancer Agents Med Chem (Formerly Current Medicinal Chemistry-Anti-Cancer Agents). 7 (2007) 484-491.

[30] N. Wang, L. Ye, B. Zhao, J. Yu, Spectroscopic studies on the interaction of efonidipine with bovine serum albumin, Brazil. J. Med. Biol. Res. 41 (2008) 589-595.

[31] S. SHAO, J. QIU, Effecting of metal ions on the interaction between zidovudine and bovine serum albumin, Acta Physico-Chimica Sinica. 25 (2009) 1342-1346.

[32] Y.-P. Wang, Y.-1. Wei, C. Dong, Study on the interaction of 3, 3-bis (4-hydroxy-1-naphthyl)-phthalide with bovine serum albumin by fluorescence spectroscopy, J. Photochem. Photobiol A. 177 (2006) 6-11.

[33] J. Tian, J. Liu, Z. Hu, X. Chen, Interaction of wogonin with bovine serum albumin, Bioorg. Med. Chem. 13 (2005) 4124-4129.

[34] K. Karami, M. Hosseini-Kharat, H. Sadeghi-Aliabadi, J. Lipkowski, M. Mirian, In vitro cytotoxicity studies of palladacyclic complexes containing the symmetric diphosphine bridging ligand. Studies of their interactions with DNA and BSA, Eur. J. Med. Chem. 73 (2014) 8-17.

[35] K. Karami, Z. Shirani-Sarmazeh, M. Hosseini-Kharat, J. Lipkowski, M. Saeidifar, Synthesis, spectral characterization, crystal structure and in vitro DNA/protein binding studies of phosphorous ylide palladacyclic complexes containing azide group, J. Photochem. Photobiol B. 144 (2015) 11-19.

[36] K. Karami, Z.M. Lighvan, S.A. Barzani, A.Y. Faal, M. Poshteh-Shirani, T. Khayamian, V. Eigner, M. Dušek, Design and synthesis of a novel trinuclear palladium (ii) complex containing an oxime chelate ligand: determining the interaction mechanism with the DNA groove and BSA site I by spectroscopic and molecular dynamics simulation approaches, New J. Chem. 39 (2015) 8708-8719.

[37] K. Karami, H. Sadeghi-Aliabadi, J. Lipkowski, M. Mirian, Dinuclear bridged biphosphinic and mononuclear cyclopalladated complexes of benzylamines: Synthesis, structural characterization and antitumor activity, Polyhedron 50 (2013) 187-192.

[38] R. Clark, J. Reid, The analytical calculation of absorption in multifaceted crystals, Acta Crystallographica Section A: Foundations of Crystallography 51 (1995) 887-897.

[39] A.D. Becke, Density- functional thermochemistry. III. The role of exact exchange, J. Chem. Phys. 98 (1993) $5648-5652$.

[40] Wallingford, C. Gaussian , Inc., revision B.01; $2009 .$.

[41] G.M. Morris, R. Huey, W. Lindstrom, M.F. Sanner, R.K. Belew, D.S. Goodsell, A.J. Olson, AutoDock4 and AutoDockTools4: Automated docking with selective receptor flexibility, J. Comput. Chem. 30 (2009) 2785-2791.

[42] G.M. Morris, D.S. Goodsell, R.S. Halliday, R. Huey, W.E. Hart, R.K. Belew, A.J. Olson, Automated docking using a Lamarckian genetic algorithm and an empirical binding free energy function, J. Comput. Chem. 19 (1998) 1639-1662.

[43] C. Hetényi, D. van der Spoel, Efficient docking of peptides to proteins without prior knowledge of the binding site, Protein Sci. 11 (2002) 1729-1737.

[44] C. Hetényi, D. van der Spoel, Blind docking of drug-sized compounds to proteins with up to a thousand residues, FEBS letters 580 (2006) 1447-1450.

[45] http://www.molegro.com/index.phpof Computational Chemistry 2004, 25, 1605-1612. 
[46] E.F. Pettersen, T.D. Goddard, C.C. Huang, G.S. Couch, D.M. Greenblatt, E.C. Meng, T.E. Ferrin, UCSF Chimera - a visualization system for exploratory research and analysis, J. Comput. Chem. 25 (2004) 16051612.

[47] D.S. BIOVIA, Discovery Studio Modeling Environment, San Diego, Dassault Systemes, Release 4 (2013).

[48] A. Koch, P. Tamez, J. Pezzuto, D. Soejarto, Evaluation of plants used for antimalarial treatment by the Maasai of Kenya, J Ethnopharmacol. 101 (2005) 95-99.

[49] M.C. Gimeno, A. Laguna, C. Sarroca, P.G. Jones, 1, 1'-Bis (diphenylphosphino) ferrocene (dppf) complexes of gold (I) and gold (III). Crystal structures of [(dppf) AuPPh3] ClO4. cntdot. $\mathrm{CHCl} 3$ and [(dppf) $\mathrm{Au}$ (. mu.dppf) $\mathrm{Au}(\mathrm{dppf})](\mathrm{ClO} 4)$ 2. cntdot. 2CH2Cl2, Inorg. Chem. 32 (1993) 5926-5932.

[50] G. Bandoli, A. Dolmella, Ligating ability of 1, 1'-bis (diphenylphosphino) ferrocene: a structural survey (19941998), Coord. Chem. Rev. 209 (2000) 161-196.

[51] J.M. Vila, E. Gayoso, T. Pereira, M. Mariño, J. Martínez, J.J. Fernández, A. Fernández, M. López-Torres, Novel cyclopalladated ferrocenyl Schiff base compounds with bridging and chelating diphosphines. Crystal

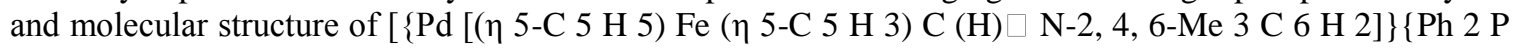
(CH 2) n PPh 2 $\square$ P, P \}][PF 6](n= 1, 2), J. Organomet. Chem. 637 (2001) 577-585.

[52] S.R. Ananias, A.E. Mauro, V.A. de Lucca Neto, Cleavage of the dimeric cyclopalladated [Pd (N, C-dmba) $(\mu-$ $\mathrm{X})$ ] 2, (dmba= N, N-dimethylbenzylamine; $\mathrm{X}=\mathrm{SCN}$ and $\mathrm{NCO})$ by diphosphines. Palladium (II) compounds with distinct structures in the solid-state and in solution, Transition Met. Chem. 26 (2001) 570-573.

[53] E.C. Long, J.K. Barton, On demonstrating DNA intercalation, Acc. Chem. Res. 23 (1990) 271-273.

[54] A. Pyle, J. Rehmann, R. Meshoyrer, C. Kumar, N. Turro, J.K. Barton, Mixed-ligand complexes of ruthenium (II): factors governing binding to DNA, J. Am. Chem. Soc. 111 (1989) 3051-3058.

[55] M. Waring, Variation of the supercoils in closed circular DNA by binding of antibiotics and drugs: evidence for molecular models involving intercalation, J. Mol. Biol. 54 (1970) 247-279.

[56] T.-R. Li, Z.-Y. Yang, B.-D. Wang, D.-D. Qin, Synthesis, characterization, antioxidant activity and DNAbinding studies of two rare earth (III) complexes with naringenin-2-hydroxy benzoyl hydrazone ligand, Eur. J. Med. Chem. 43 (2008) 1688-1695.

[57] J. Liu, H. Zhang, C. Chen, H. Deng, T. Lu, L. Ji, Interaction of macrocyclic copper (II) complexes with calf thymus DNA: effects of the side chains of the ligands on the DNA-binding behaviors, Dalton Trans. (2003) 114-119.

[58] M.N. Patel, H.N. Joshi, C.R. Patel, Cytotoxic, antibacterial, DNA interaction and superoxide dismutase like activities of sparfloxacin drug based copper (II) complexes with nitrogen donor ligands, Acta Mol. Biomol. Spectrosc. 104 (2013) 48-55.

[59] L.-F. Tan, H. Chao, Y.-F. Zhou, L.-N. Ji, Synthesis, characterization, DNA-binding and DNA-photocleavage studies of $[\mathrm{Ru}$ (bpy) 2 (BPIP)] 2+ and [Ru (phen) 2 (BPIP)] 2+(BPIP= 2-(4'-biphenyl) imidazo [4, 5-f][1, 10] phenanthroline), Polyhedron 26 (2007) 3029-3036.

[60] L.-F. Tan, X.-H. Liu, H. Chao, L.-N. Ji, Synthesis, DNA-binding and photocleavage studies of ruthenium (II) complex with 2-(3'-phenoxyphenyl) imidazo [4, 5-f][1, 10] phenanthroline, J. Inorg. Biochem. 101 (2007) $56-63$.

[61] C.-W. Ong, J.-Y. Jeng, S.-S. Juang, C.-F. Chen, A ferrocene-intercalator conjugate with a potent cytotoxicity, Bioorg. Med. Chem. Lett. 2 (1992) 929-932.

[62] M.T. Carter, M. Rodriguez, A.J. Bard, Voltammetric studies of the interaction of metal chelates with DNA. 2. Tris-chelated complexes of cobalt (III) and iron (II) with 1, 10-phenanthroline and 2, 2'-bipyridine, J. Am. Chem. Soc. 111 (1989) 8901-8911.

[63] N. Yoshioka, H. Inoue, DNA binding of iron (II) mixed-ligand complexes containing 1, 10-phenanthroline and 4, 7-diphenyl-1, 10-phenanthroline, J. Inorg. Biochem. 77 (1999) 239-247.

[64] A. Dimitrakopoulou, C. Dendrinou-Samara, A.A. Pantazaki, M. Alexiou, E. Nordlander, D.P. Kessissoglou, Synthesis, structure and interactions with DNA of novel tetranuclear,[Mn 4 (II/II/II/IV)] mixed valence complexes, J. Inorg. Biochem. 102 (2008) 618-628.

[65] N. Chitrapriya, T.S. Kamatchi, M. Zeller, H. Lee, K. Natarajan, Synthesis, spectroscopic, crystal structure and DNA binding of Ru (II) complexes with 2-hydroxy-benzoic acid [1-(4-hydroxy-6-methyl-2-oxo-2H-pyran3-yl)-ethylidene]-hydrazide, Acta Mol. Biomol. Spectrosc. 81 (2011) 128-134.

[66] J.R. Lakowicz, G. Weber, Quenching of fluorescence by oxygen. Probe for structural fluctuations in macromolecules, Biochemistry. 12 (1973) 4161-4170.

[67] B.C. Baguley, M. Le Bret, Quenching of DNA-ethidium fluorescence by amsacrine and other antitumor agents: a possible electron-transfer effect, Biochemistry 23 (1984) 937-943. 
[68] S. Arounaguiri, B.G. Maiya, Dipyridophenazine complexes of cobalt (III) and nickel (II): DNA-binding and photocleavage studies, Inorg. Chem. 35 (1996) 4267-4270.

[69] L.Z. Zhang, P. Cheng, Study of Ni (II) ion-DNA interactions with methylene blue as fluorescent probe, J. Inorg. Biochem. 98 (2004) 569-574.

[70] M. Bordbar, M. Tabatabaee, M. Alizadeh-Nouqi, Z. Mehri-Lighvan, H.R. Khavasi, A. YeganehFaal, F. Fallahian, M. Dolati, Synthesis, characterization, cytotoxic activity and DNA-binding studies of cobalt (II) mixed-ligand complex containing pyridine-2, 6-dicarboxylate ion and 2-aminopyrimidine, J IRAN CHEM SOC (2016) 1-8.

[71] M. Bordbar, M. Tabatabaee, A. Yeganeh Faal, Z. Mehri Lighvan, R. Fazaeli, DNA Binding Properties of Water-Soluble Mixed Ligand Nickel (II) Complex with Calf-thymus DNA Using Different Instrumental Methods, Synth React Inorg Met Org Chem. 45 (2015) 1882-1888.

[72] D.L. Arockiasamy, S. Radhika, R. Parthasarathi, B.U. Nair, Synthesis and DNA-binding studies of two ruthenium (II) complexes of an intercalating ligand, Eur. J. Med. Chem. 44 (2009) 2044-2051.

[73] G.F. Calvo, R.F. Alvarez-Estrada, The time duration for DNA thermal denaturation, J. Phys. Condens. Matter.20 (2007) 035101.

[74] E. Tselepi-Kalouli, N. Katsaros, The interaction of [Ru (NH3) 5Cl] 2+ and [Ru (NH3) 6] 3+ ions with DNA, J. Inorg. Biochem. 37 (1989) 271-282.

[75] M. Waring, Complex formation between ethidium bromide and nucleic acids, J. Inorg. Biochem. 13 (1965) 269-282.

[76] G.A. Neyhart, N. Grover, S.R. Smith, W.A. Kalsbeck, T.A. Fairley, M. Cory, H.H. Thorp, Binding and kinetics studies of oxidation of DNA by oxoruthenium (IV), J. Am. Chem. Soc. 115 (1993) 4423-4428.

[77] D.S. Raja, N.S. Bhuvanesh, K. Natarajan, Synthesis, crystal structure and pharmacological evaluation of two new $\mathrm{Cu}$ (II) complexes of 2-oxo-1, 2-dihydroquinoline-3-carbaldehyde (benzoyl) hydrazone: A comparative investigation, Eur. J. Med. Chem. 47 (2012) 73-85.

[78] X. Zhao, R. Liu, Z. Chi, Y. Teng, P. Qin, New insights into the behavior of bovine serum albumin adsorbed onto carbon nanotubes: comprehensive spectroscopic studies, J. Phys. Chem. B. 114 (2010) 5625-5631.

[79] F. Samari, B. Hemmateenejad, M. Shamsipur, M. Rashidi, H. Samouei, Affinity of two novel five-coordinated anticancer Pt (II) complexes to human and bovine serum albumins: a spectroscopic approach, Inorg. Chem. 51 (2012) 3454-3464.

[80] Y. He, Y. Wang, L. Tang, H. Liu, W. Chen, Z. Zheng, G. Zou, Binding of puerarin to human serum albumin: a spectroscopic analysis and molecular docking, J fluoresc. 18 (2008) 433-442.

[81] X.-W. Li, X.-J. Li, Y.-T. Li, Z.-Y. Wu, C.-W. Yan, Syntheses and structures of new trimetallic complexes bridged by $\mathrm{N}$-(5-chloro-2-hydroxyphenyl)-N'-[3-(dimethylamino) propyl] oxamide: Cytotoxic activities, and reactivities towards DNA and protein, J. Photochem. Photobiol. B, Biol. 118 (2013) 22-32.

[82] M. Anjomshoa, H. Hadadzadeh, M. Torkzadeh-Mahani, S.J. Fatemi, M. Adeli-Sardou, H.A. Rudbari, V.M. Nardo, A mononuclear $\mathrm{Cu}$ (II) complex with 5, 6-diphenyl-3-(2-pyridyl)-1, 2, 4-triazine: synthesis, crystal structure, DNA-and BSA-binding, molecular modeling, and anticancer activity against MCF-7, A-549, and HT-29 cell lines, Eur. J. Med. Chem. 96 (2015) 66-82.

[83] O. Stern, M. Volmer, The extinction period of fluorescence, Phys. Z 20 (1919) 183-188.

[84] R.L. Joseph, R. Lakowicz, Principles of fluorescence spectroscopy, Kluwer Academic/Plenum Publishers, New York, 1999.

[85] S. Lehrer, Solute perturbation of protein fluorescence. Quenching of the tryptophyl fluorescence of model compounds and of lysozyme by iodide ion, Biochemistry 10 (1971) 3254-3263.

[86] Y.-Z. Zhang, B. Zhou, X.-P. Zhang, P. Huang, C.-H. Li, Y. Liu, Interaction of malachite green with bovine serum albumin: determination of the binding mechanism and binding site by spectroscopic methods, $\mathrm{J}$. Hazard. Mater. 163 (2009) 1345-1352.

[87] U. Kragh-Hansen, Molecular aspects of ligand binding to serum albumin, Pharmacol Rev. 33 (1981) 17-53.

[88] N. Dubois, F. Lapicque, J. Magdalou, M. Abiteboul, P. Netter, Stereoselective binding of the glucuronide of ketoprofen enantiomers to human serum albumin, Biochem Pharmacol. 48 (1994) 1693-1699.

[89] Q. Wang, X. Liu, M. Su, Z. Shi, H. Sun, Study on the interaction characteristics of dexamethasone sodium phosphate with bovine serum albumin by spectroscopic technique, New. J. Chem. 38 (2014) 4092-4098.

[90] M.P. Heng, S.K. Sinniah, W.Y. Teoh, K.S. Sim, S.W. Ng, Y.K. Cheah, K.W. Tan, Synthesis of a DNAtargeting nickel (II) complex with testosterone thiosemicarbazone which exhibits selective cytotoxicity towards human prostate cancer cells (LNCaP), Spectrochim. Acta Mol. Biomol. Spectrosc. 150 (2015) 360372. 
[91] F. Liu, X. Wang, X. Han, X. Tan, W. Kang, Cytotoxicity and DNA interaction of brucine and strychnine-Two alkaloids of semen strychni, Int. J. Biol. Macromolec. 77 (2015) 92-98.

[92] Omae, I., Applications of five-membered ring products of cyclometalation reactions as anticancer agents. Coord. Chem. Rev. 2014, 280, 84-95.

[93] M. Rakad, A. Jumaily, Evaluation of anticancer activities of crude extracts of Apium graveolens L. Seeds in two cell lines, RD and L20B in vitro, IJCMG. 3 (2010) 20-23.

[94] R.M. Vaden, K.M. Gligorich, R. Jana, M.S. Sigman, B.E. Welm, The small molecule C-6 is selectively cytotoxic against breast cancer cells and its biological action is characterized by mitochondrial defects and endoplasmic reticulum stress, Breast Cancer Res. 16 (2014) 1-12.

[95] L.R. Kelland, B.A. Murrer, G. Abel, C.M. Giandomenico, P. Mistry, K.R. Harrap, Ammine/amine platinum (IV) dicarboxylates: a novel class of platinum complex exhibiting selective cytotoxicity to intrinsically cisplatin-resistant human ovarian carcinoma cell lines, Cancer res. 52 (1992) 822-828.

[96] J.L. Hickey, R.A. Ruhayel, P.J. Barnard, M.V. Baker, S.J. Berners-Price, A. Filipovska, Mitochondria-targeted chemotherapeutics: the rational design of gold (I) N-heterocyclic carbene complexes that are selectively toxic to cancer cells and target protein selenols in preference to thiols, Am. Chem. Soc. 130 (2008) 1257012571.

[97] V. Zuco, R. Supino, S.C. Righetti, L. Cleris, E. Marchesi, C. Gambacorti-Passerini, F. Formelli, Selective cytotoxicity of betulinic acid on tumor cell lines, but not on normal cells, Cancer lett. 175 (2002) 17-25. 


\section{Figure captions:}

Scheme 1. Schematic representation of synthetic strategy

Scheme 2. Ideal conformations of dppf arising from Cp (centroid) $\cdots$..Fe... Cp (centroid) twist angle

Figure 1. ORTEP view of complex 2 at 30\% thermal ellipsoid probability, and partial labelling with only the heteroatoms labelled. $\mathrm{H}$ atoms and the solvent $\left(\mathrm{CH}_{2} \mathrm{Cl}_{2}\right)$ have been omitted for clarity. Selected bond lengths $(\AA)$, and angles $\left({ }^{\circ}\right)$ : Pd1-Cl4 2.407(9), Pd2-Cl5 2.403(10), Pd1-P4 2.268(10), Pd2-P5 2.253(9), Pd1-N2 2.011(4), Pd2-N1 2.101(3), N2- Pd1 -C30 83.46(14), N1- Pd2-C1 85.51(15), C30-Pd1-P4 96.81(11), C1-Pd2-P5 96.71(11), N2-Pd1Cl4 88.97(9), N1-Pd2-CL5 87.11(9), C14-Pd1-P4 113.03(13), C18-Pd2-P5 107.99(12).

Figure. 2. 1D polymeric chain along c-axis, showing intermolecular hydrogen bonds

Figure. 3. Packing diagram of complex 2, formed by $\mathrm{N} 2 \mathrm{H} 2 \ldots \mathrm{Cl} 5$ intermolecular hydrogen bonds and $\mathrm{CH} \ldots . . \pi$ interactions, creating 2D aggregations.

Figure .4. Packing diagram of solvent molecules $\left(\mathrm{CH}_{2} \mathrm{Cl}_{2}\right.$ atoms) along the axis $\mathrm{b}$ formed by $\mathrm{N} 1 \mathrm{H} \ldots \mathrm{Cl}$ intermolecular hydrogen bonds

Figure 5. Plots of the changes of absorbance at $260 \mathrm{~nm}$ of CT-DNA $\left(7.5 \times 10^{-6} \mathrm{~mol} \mathrm{~L}^{-1}\right)$ on heating in the absence and presence of the complexes $\left(37.5 \times 10^{-6} \mathrm{~mol} \mathrm{~L}^{-1}\right)$ in $5 \mathrm{mMTris}-\mathrm{HCl}$ with $50 \mathrm{mMNaCl}$

Figure 6. Fluorescence spectra of BSA in the different concentrations of 2 and 3 at room temperature. $C(\mathrm{BSA})=4 \times$ $10^{-6} \mathrm{~mol} \mathrm{~L}{ }^{-1}, C($ complex $)=0-3.9 \times 10^{-6} \mathrm{~mol} \mathrm{~L}^{-1}$. Arrow shows the change upon the increasing complex concentration. Inset: Plots of $\mathrm{I}_{0} / \mathrm{I}$ vs.

Figure 7. Influence of selected site markers on the fluorescence of complexes bound to BSA $\left(T=298 \mathrm{~K}, \lambda_{\mathrm{ex}}=285\right.$ $\mathrm{nm})$. (A) $C(\mathrm{BSA})=C($ Warfarin $)=4 \times 10^{-6} \mathrm{~mol} \mathrm{~L}^{-1} ;(\mathrm{B}) C(\mathrm{BSA})=C($ Ibuprofen $)=4 \times 10^{-6} \mathrm{~mol} \mathrm{~L}^{-1} ;(\mathrm{C}) C(\mathrm{BSA})=$ $C($ Digoxin $)=4 \times 10^{-6} \mathrm{~mol} \mathrm{~L}^{-1}, C($ complex $)=0-3.9 \times 10^{-6} \mathrm{~mol} \mathrm{~L}^{-1}$

Figure 8. Results of docking procedure. (A) Predicted orientations of the lowest docking energy conformations of complex 2 with the intercalation of DNA using UCSF chimera. (B) Two dimensional interactions between complex 2 and DNA generated by Discovery Studio Visualizer

Figure 9. Results of docking procedure. (A) Predicted orientations of the lowest docking energy conformations of complex 3 with the intercalation of DNA using UCSF chimera. (B) Two dimensional interactions between complex 3 and DNA generated by Discovery Studio Visualizer

Figure 10. Results of docking procedure. (A) Predicted orientations of the lowest docking energy conformations of complex 2 with the BSA using Molegro Molecular viewer. (B) Two dimensional interactions between complex 1 and BSA generated by Discovery Studio Visualizer 
Figure 11. Results of docking procedure. (A) Predicted orientations of the lowest docking energy conformations of complex 3 with the BSA using Molegro Molecular viewer. (B) Two dimensional Interactions between complex 2 and BSA generated by Discovery Studio Visualize

Figure 12. Dosedependent cytotoxic activity of complexes 2 and 3 against SKOV3(A) and JURKAT (B) cancer cell lines at the concentrations of $1,4,8$ and $10 \mu \mathrm{M}$. Results are the mean \pm SD of three independent experiments. All data are significantly different from untreated control by $p<0.05$.

Table 1. Crystal Data and Structure Refinement Parameters for complex 2

Table 2.Estimated binding constants for free complexes 2, 3 and site marker competitive experiments of two Pd complex-BSA systems

Table 3. Selective cytotoxicity of complexes 2 and 3 against different cancer and normal cell lines 
Scheme 1

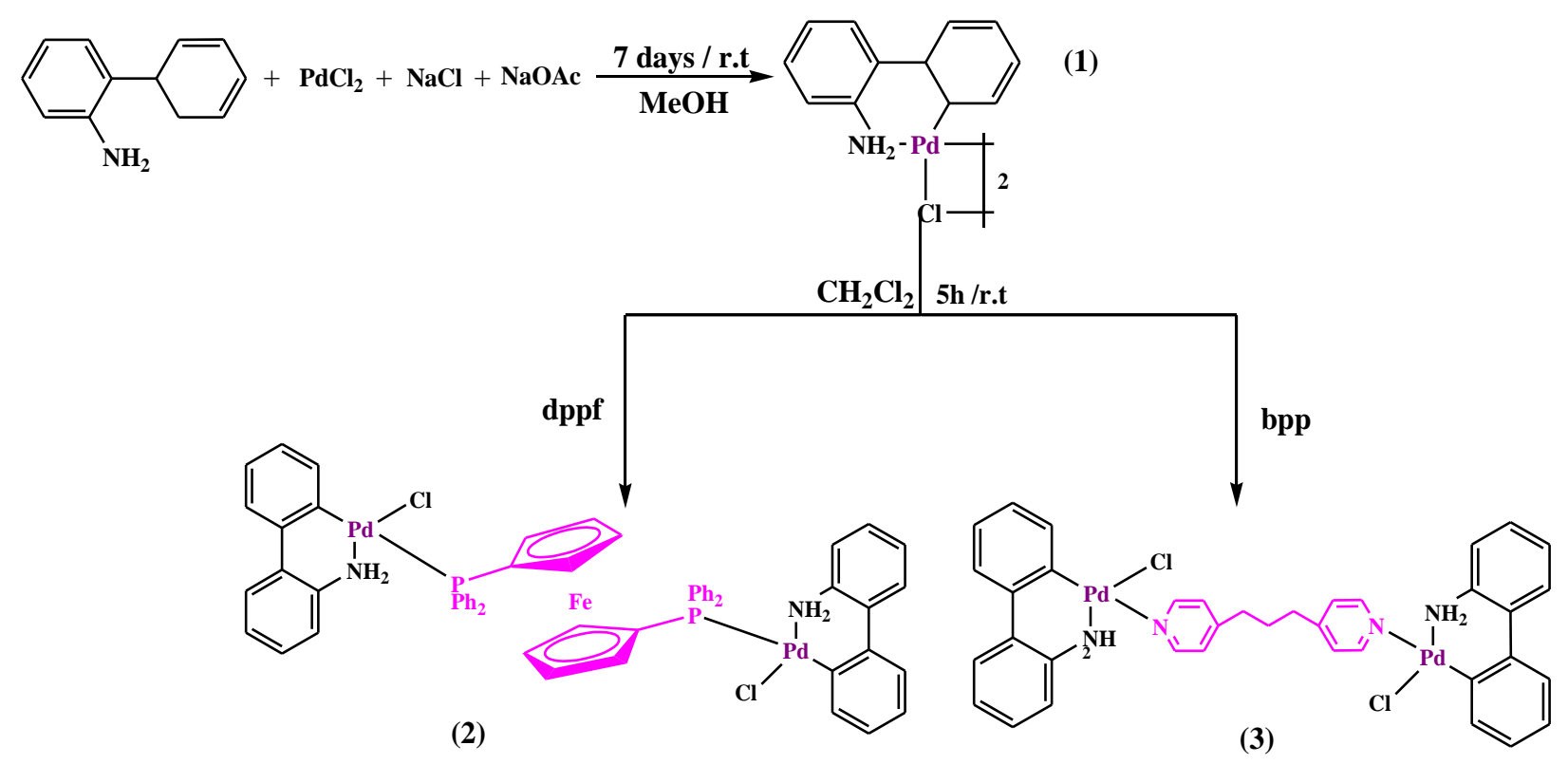

Scheme 2

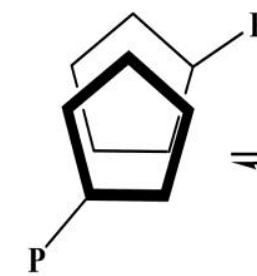

"anticlinal eclipsed" "antiperiplanar staggered"

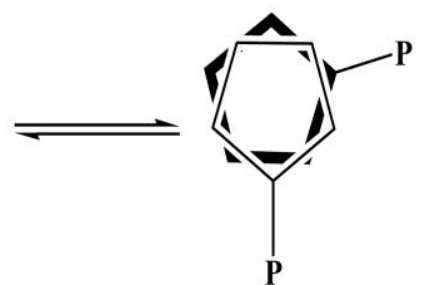

"anticlinal staggered" 
Figure 1

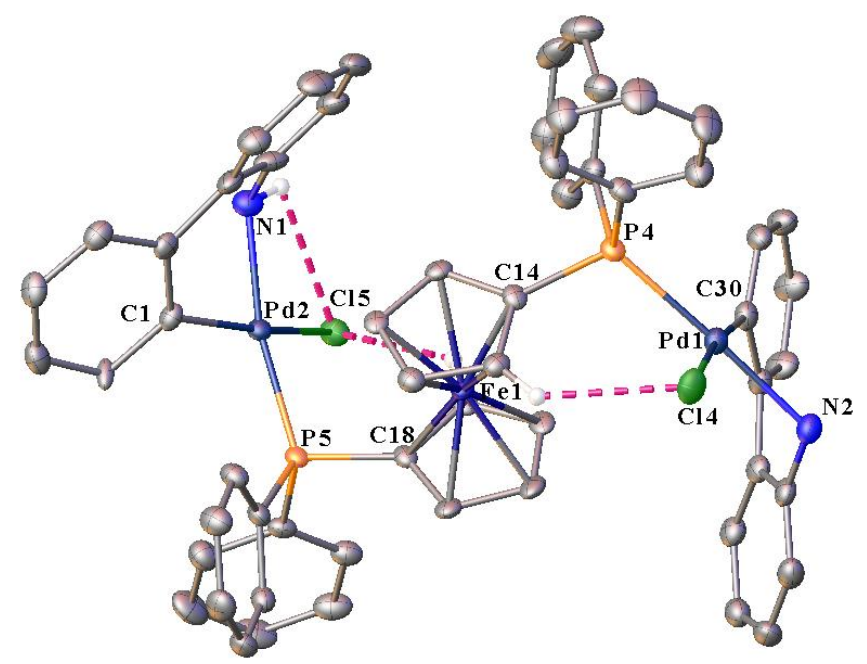

Figure. 2

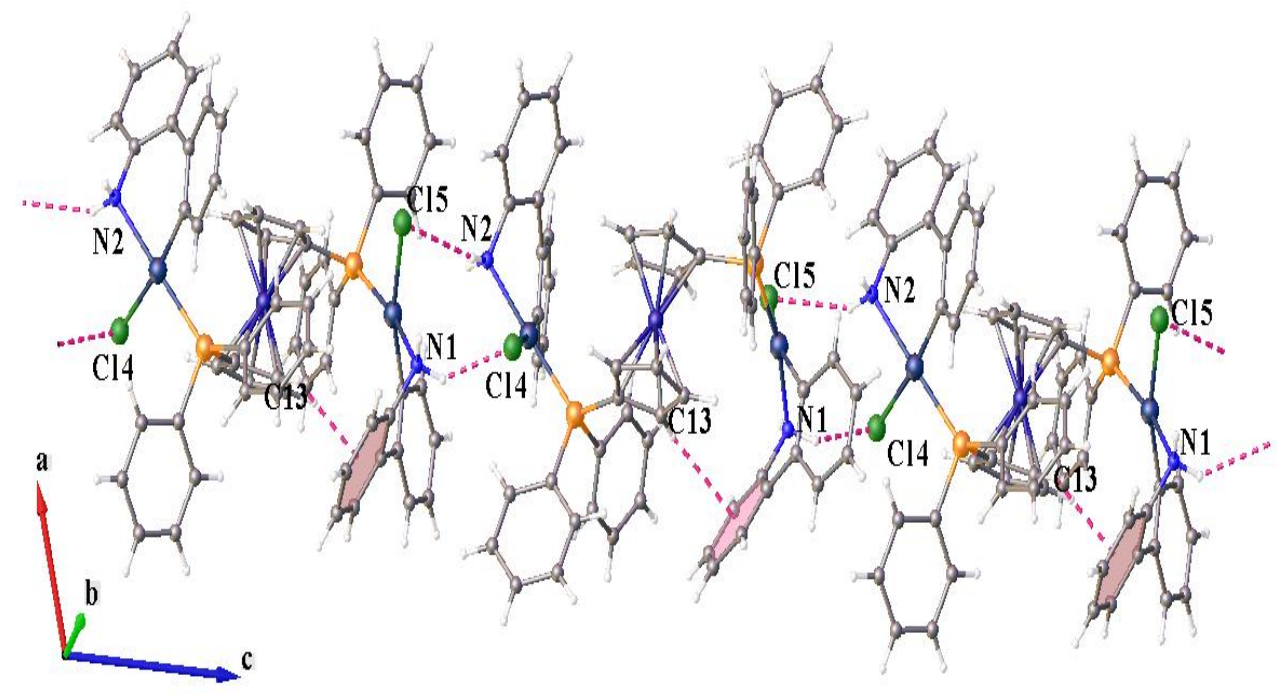


Figure. 3

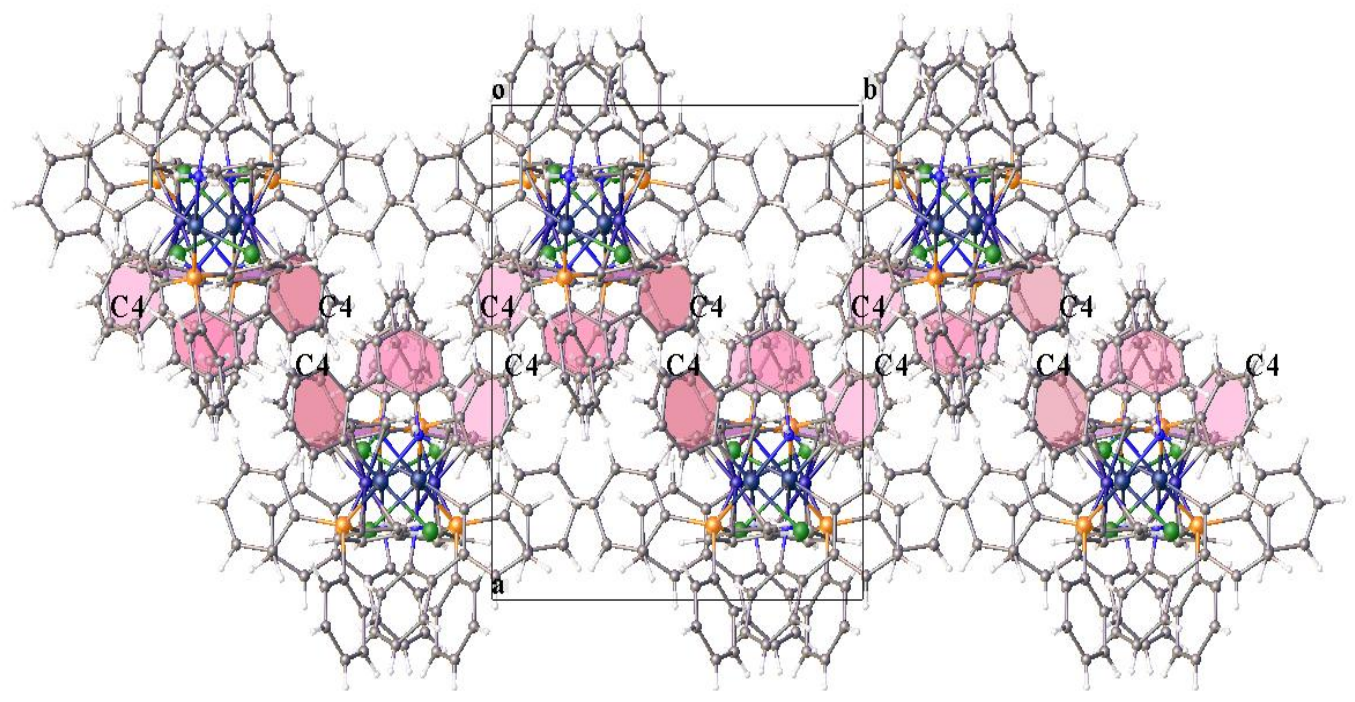

Figure 4

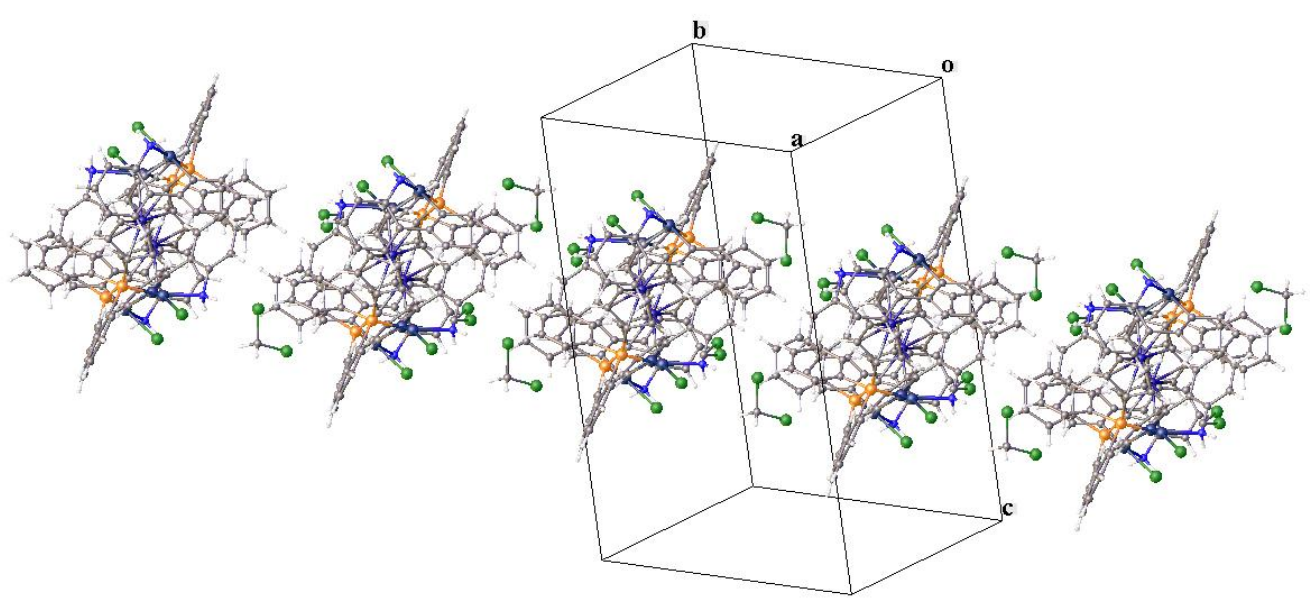


Figure 5

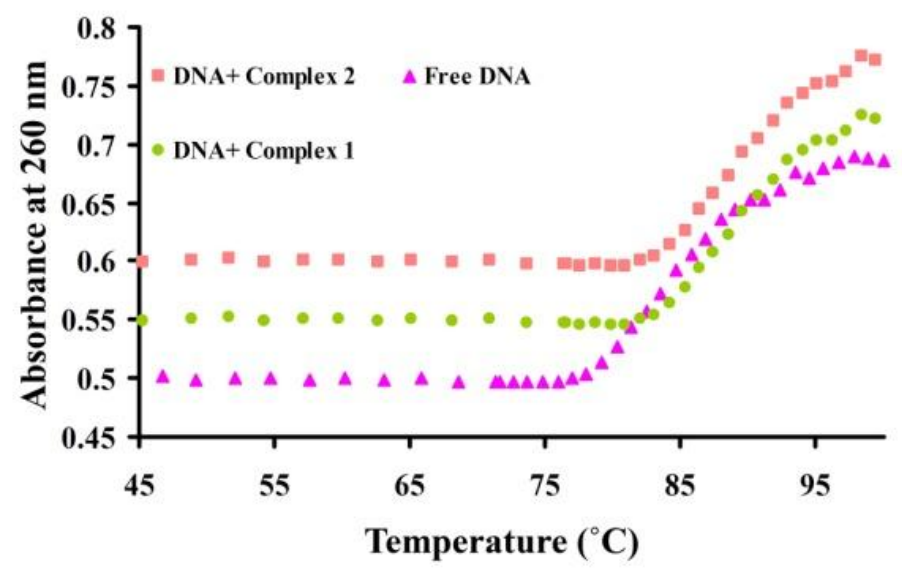

Figure 6
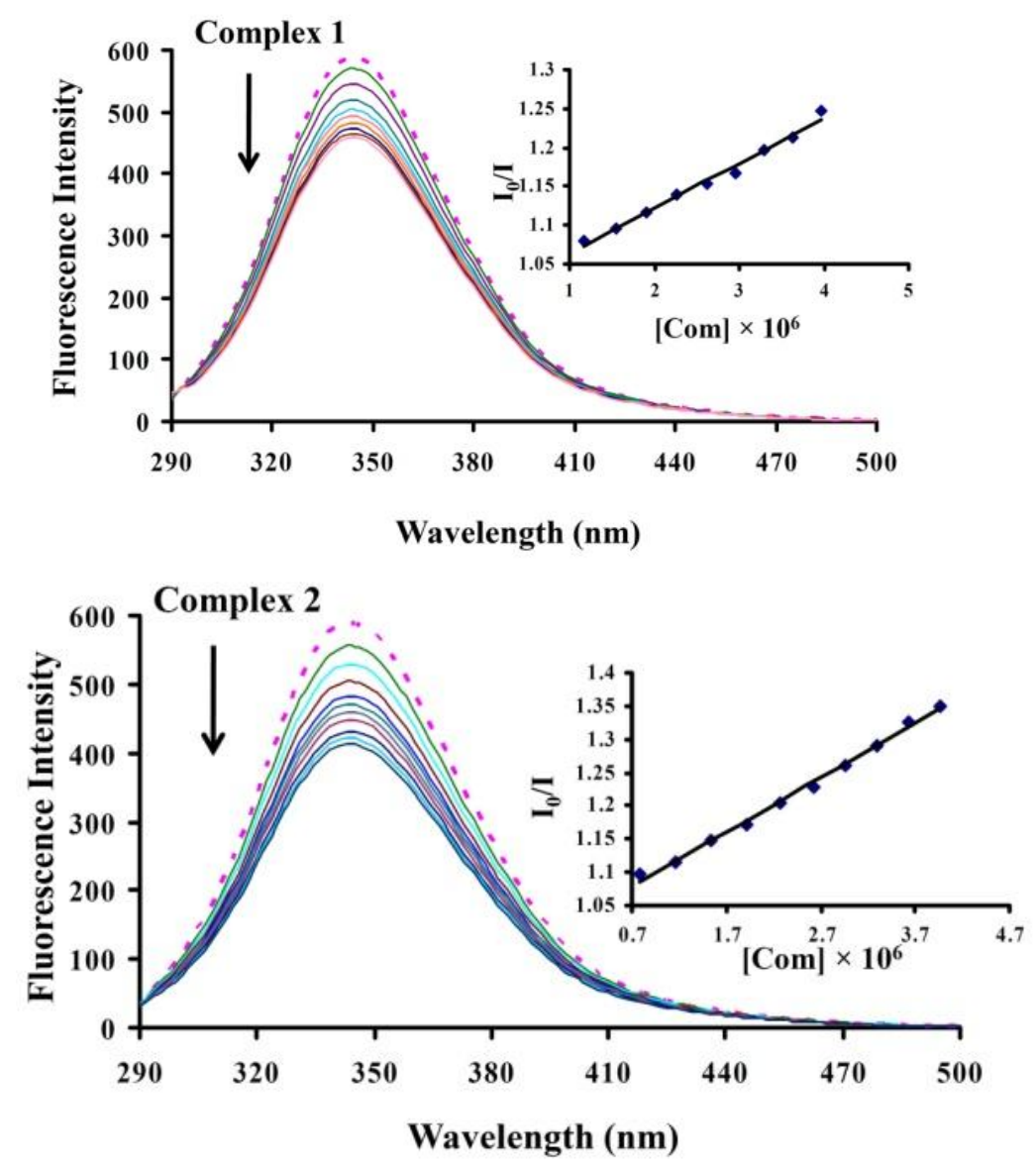
Figure 7
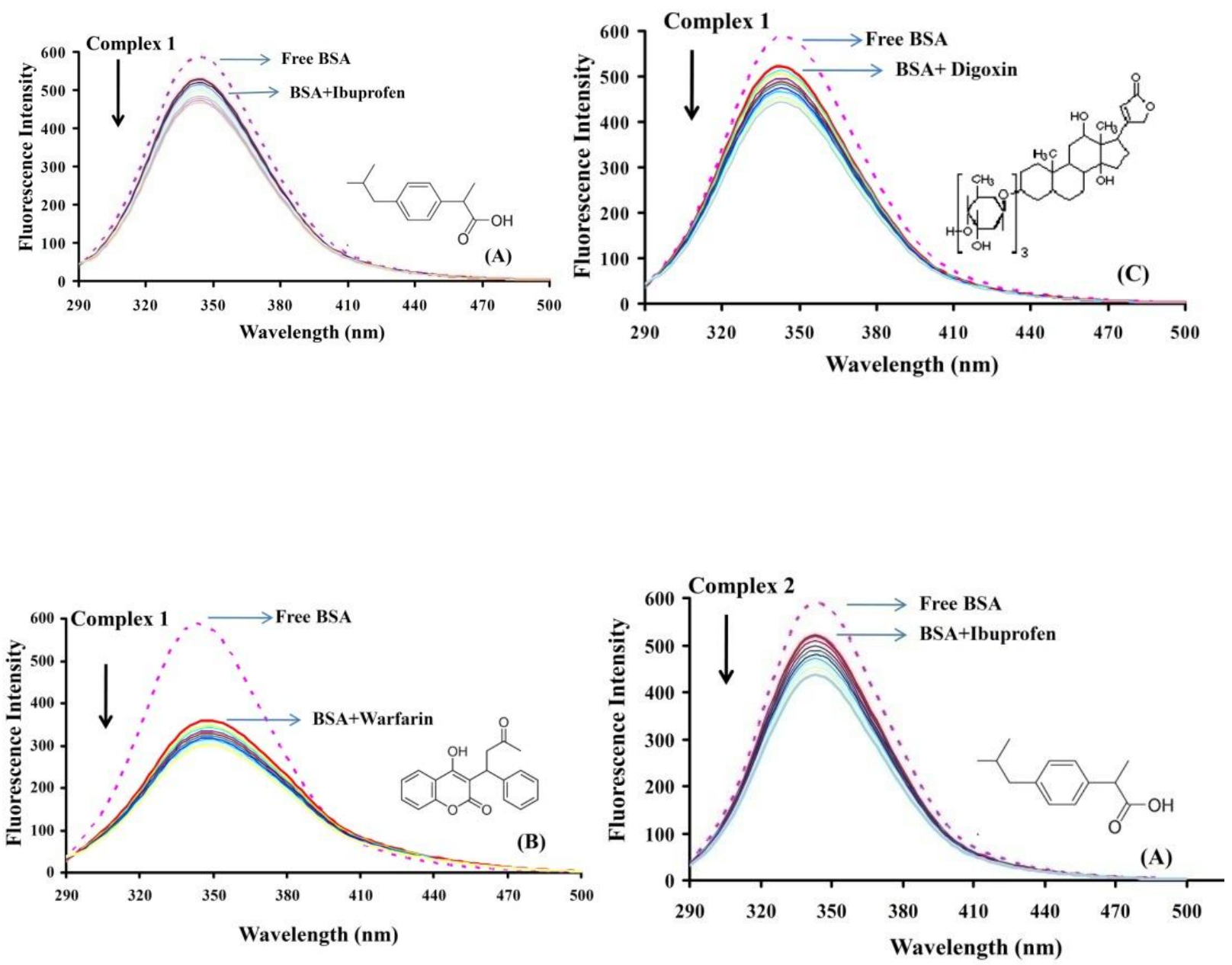

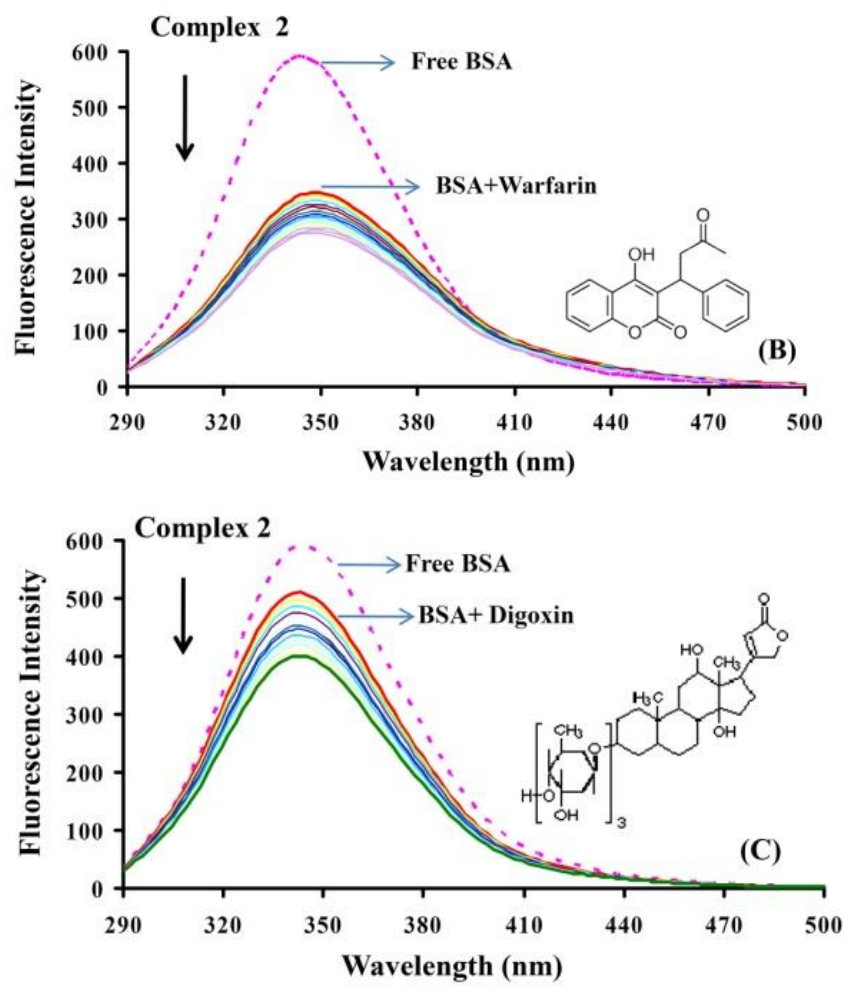

Figure 8
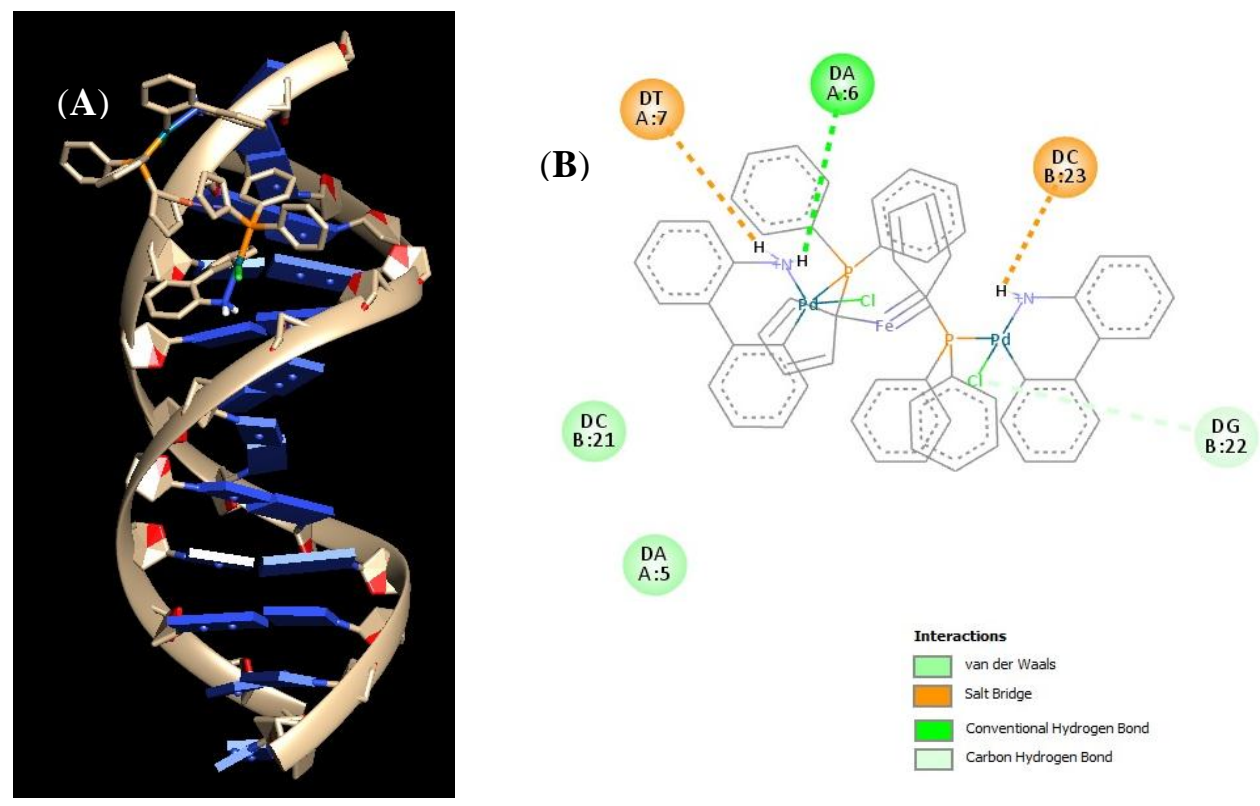
Figure 9

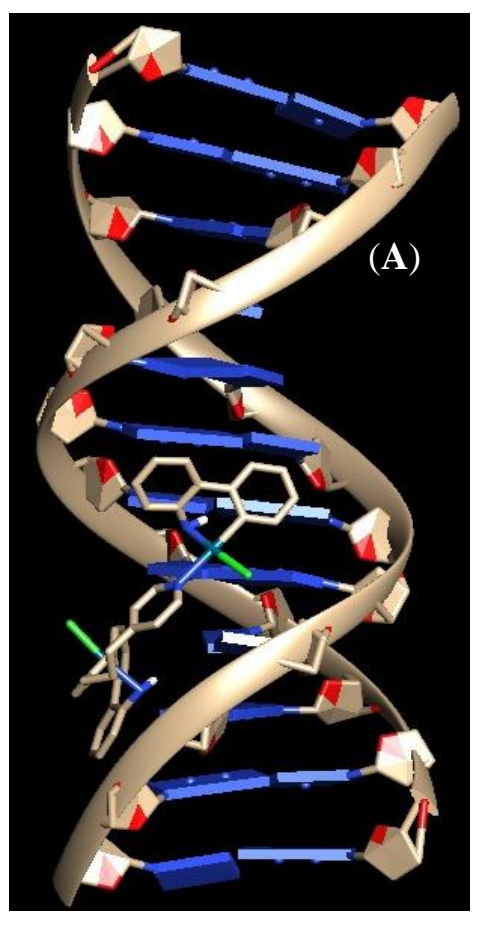

(B)

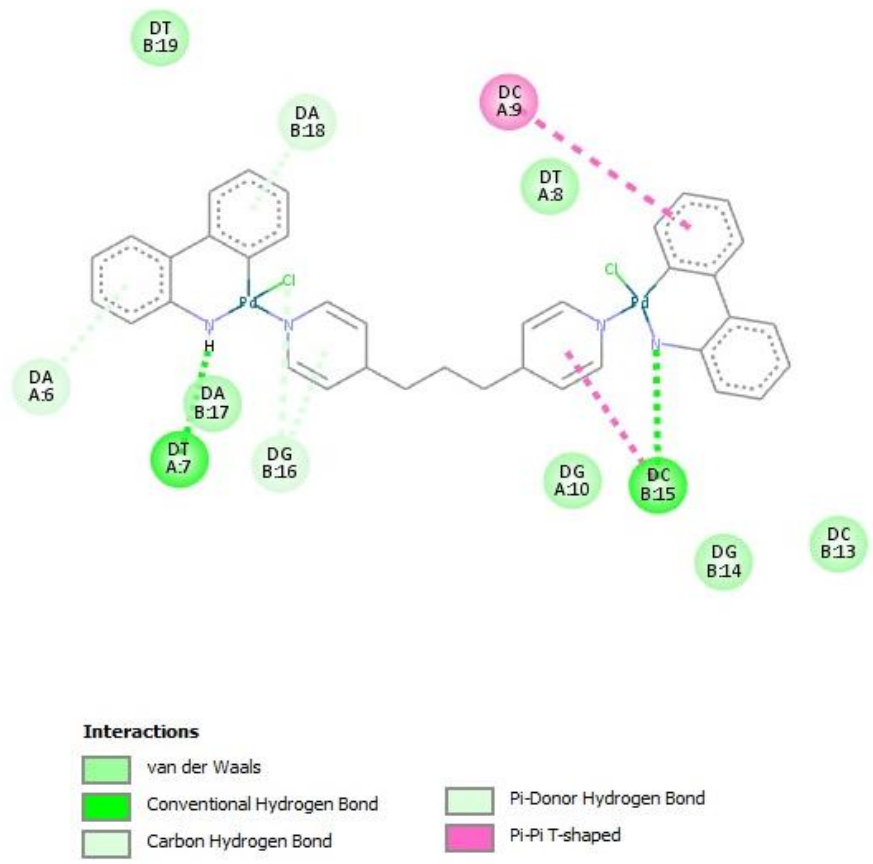


Figure 10
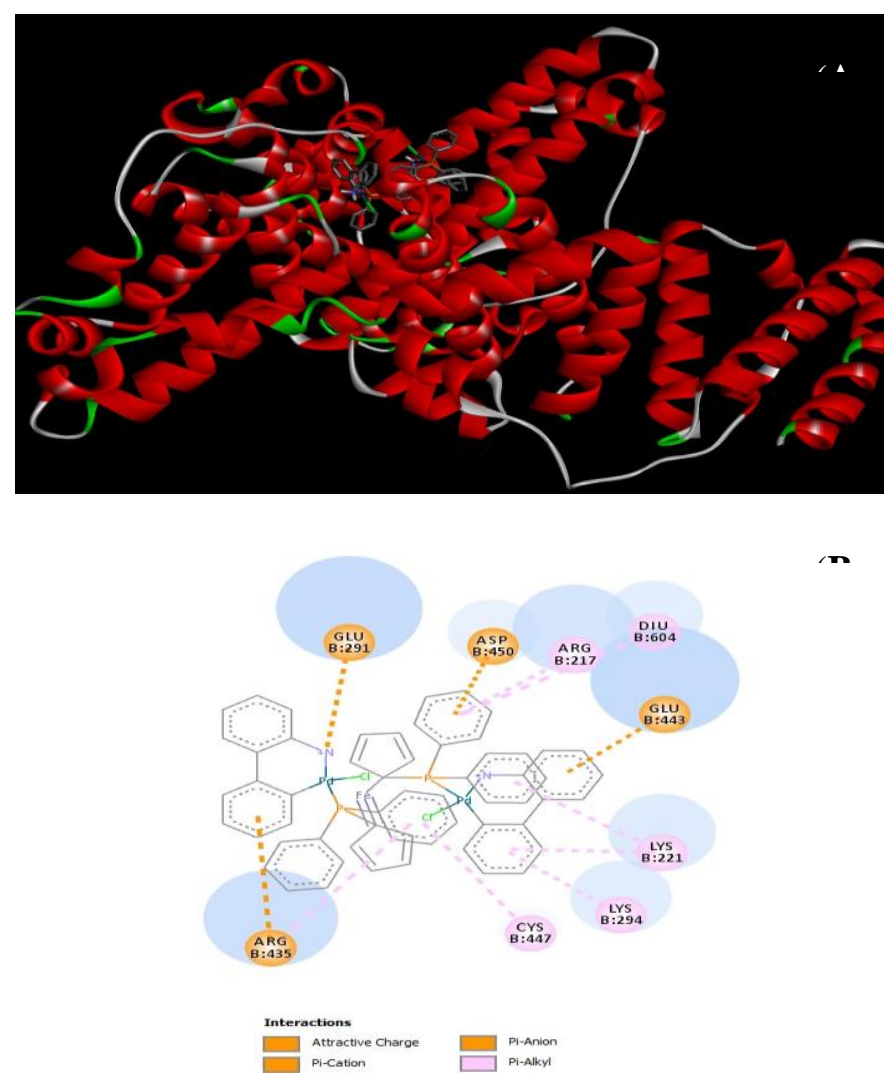
Figure 11
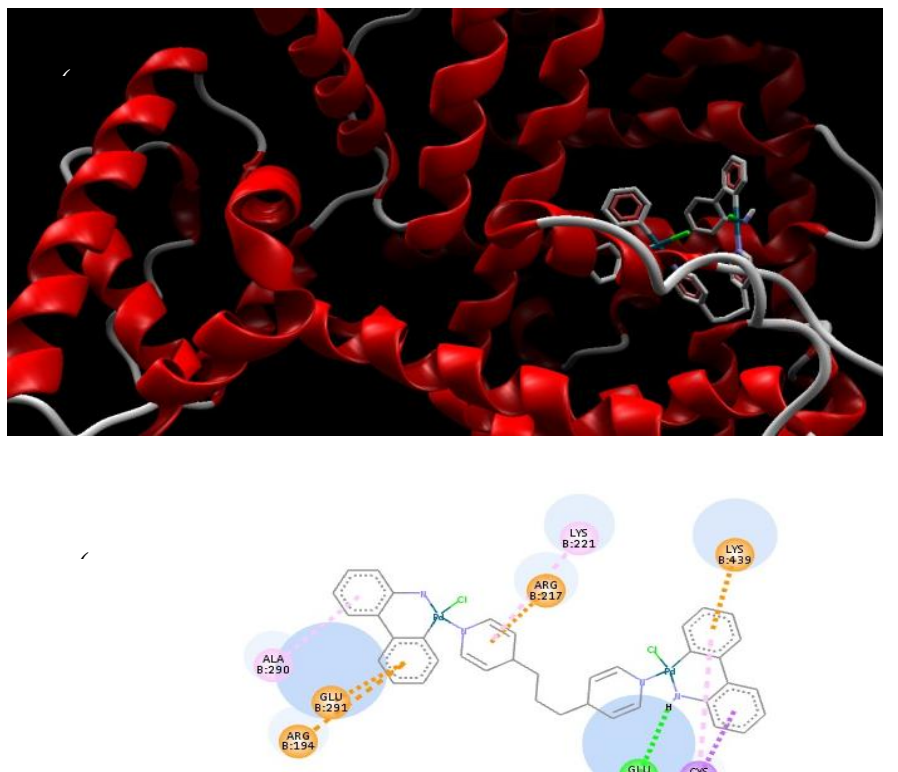

(6.4)

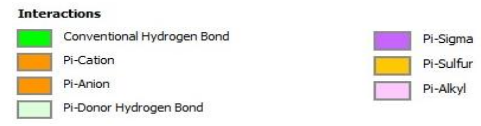

Figure 12
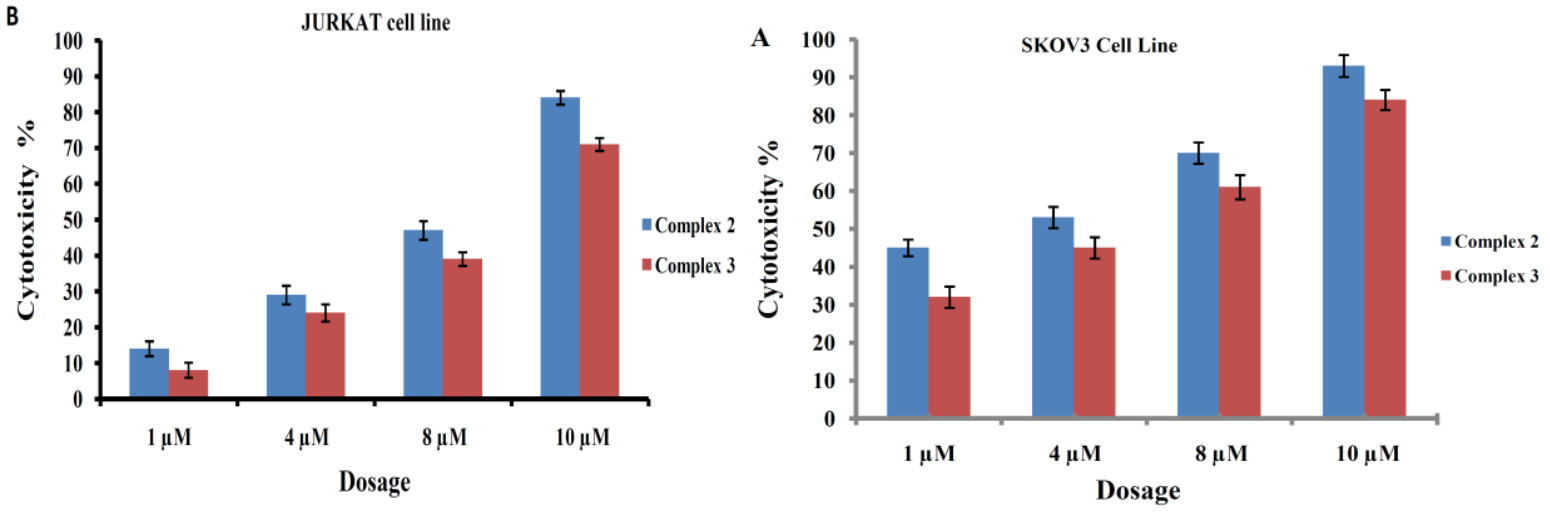
Table 1

\begin{tabular}{|c|c|}
\hline Compound & Complex \\
\hline Empirical formula & $\mathrm{C}_{61.16} \mathrm{H}_{49.78} \mathrm{Cl}_{4.95} \mathrm{FeN}_{2} \mathrm{P}_{2} \mathrm{Pd}_{2}$ \\
\hline Formula weight & 1318.65 \\
\hline Crystal system & Monoclinic \\
\hline Space group & $\mathrm{P} 2_{1} / \mathrm{c}$ \\
\hline a / $\AA$ & $16.13529(16)$ \\
\hline $\mathrm{b} / \AA$ & $13.69370(12)$ \\
\hline c / $\AA$ & $24.8730(2)$ \\
\hline$\beta /^{\circ}$ & $105.9771(10)$ \\
\hline $\mathrm{V} / \AA^{3}$ & $5283.45(8)$ \\
\hline $\mathrm{T} / \mathrm{K}$ & $100(1)$ \\
\hline $\mathrm{Z}$ & 4 \\
\hline pcalc / g cm-3 & 1.658 \\
\hline$\mu / \mathrm{mm}-1$ & 10.82 \\
\hline Crystal dimensions / mm & $0.14 \times 0.08 \times 0.04$ \\
\hline Reflections collected & 58612 \\
\hline Independent reflections (Rint) & 7581 \\
\hline GOF & 1.03 \\
\hline $\mathrm{R} 1, w \mathrm{w} 2[\mathrm{I}>3 \sigma(\mathrm{I})]$ & $0.034,0.088$ \\
\hline R1, wR2 (all data) & $0.0360,0.088$ \\
\hline Res. el. dens. (e Å-3) & $1.45,-0.89$ \\
\hline CCDC number & 1455313 \\
\hline
\end{tabular}


Table 2

\begin{tabular}{lcccccc}
\hline \multicolumn{1}{c}{ Site marker } & \multicolumn{1}{c}{$\mathbf{K}_{\text {bin }}$} & & $\mathbf{n}$ & & $\mathbf{R}$ & \\
& Complex 2 & Complex 3 & Complex 2 & Complex 3 & Complex 2 & Complex 3 \\
& $5.1 \times 10^{4}$ & $6 \times 10^{4}$ & 1.08 & 1.3 & 0.997 & 0.998 \\
Com-BSA & $3.2 \times 10^{4}$ & $4.5 \times 10^{4}$ & 1.03 & 0.96 & 0.989 & 0.999 \\
Com-BSA-Warfarin & $3.9 \times 10^{4}$ & $5.1 \times 10^{4}$ & 0.95 & 0.83 & 0.990 & 0.989 \\
Com-BSA-Ibuprofen & $4.3 \times 10^{4}$ & $5.8 \times 10^{4}$ & 0.87 & 0.90 & 0.998 & 0.988 \\
\hline Com-BSA-Digoxin & & & & & &
\end{tabular}

Table 3

\begin{tabular}{cccc}
\hline Cell line & Compound & IC $_{\mathbf{5 0}}$ & SI \\
\cline { 2 - 4 } SKOV3 & Complex 2 & $2.3 \mu \mathrm{M}$ & 16.95 \\
& Complex 3 & $5.7 \mu \mathrm{M}$ & 5.43 \\
& Cisplatin & $8.1 \mu \mathrm{M}$ & 2.96 \\
\cline { 2 - 4 } JURKAT & Complex 2 & $5.2 \mu \mathrm{M}$ & 7.5 \\
& Complex 3 & $6.7 \mu \mathrm{M}$ & 4.62 \\
& Cisplatin & $7.6 \mu \mathrm{M}$ & 3.15 \\
\cline { 2 - 4 } PBMC & Complex 2 & $39 \mu \mathrm{M}$ & - \\
& Complex 3 & $31 \mu \mathrm{M}$ & - \\
& Cisplatin & $24 \mu \mathrm{M}$ & - \\
\hline \hline
\end{tabular}




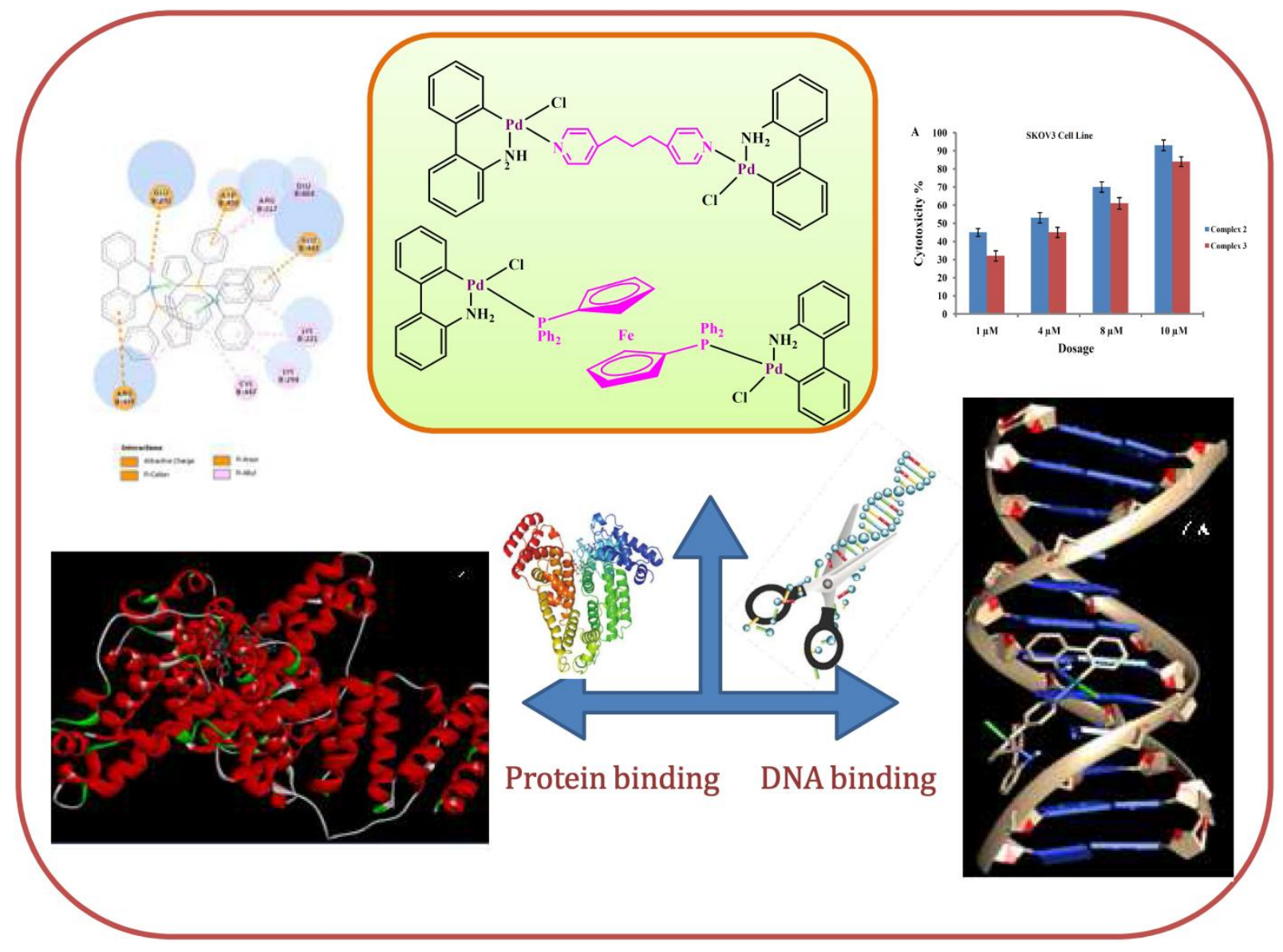

Biological palladium complexes showed significant interaction with DNA intercalative mode and BSA site I. 